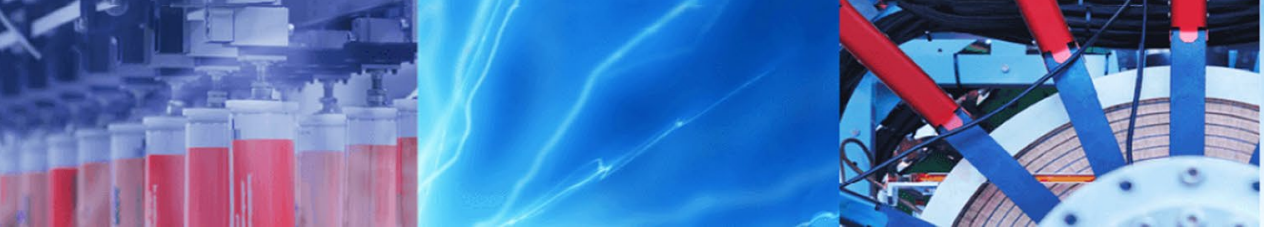

Research Article

\title{
Monazite chemistry and its distribution along the coast of Neendakara-Kayamkulam belt, Kerala, India
}

\author{
J. K. Anitha ${ }^{1} \cdot$ Sabu Joseph ${ }^{1} \cdot$ R. G. Rejith ${ }^{2} \cdot$ M. Sundararajan ${ }^{2}(1)$
}

Received: 31 October 2019 / Accepted: 24 March 2020 / Published online: 4 April 2020

(c) Springer Nature Switzerland AG 2020

\begin{abstract}
The beach sands along the coasts of India contain large reserves of strategic minerals like ilmenite, monazite, zircon, etc. Monazite mineral is primarily used as an ore for extracting rare earths particularly cerium and lanthanum. In the present study, the chemistry and distribution of monazite found in the beach sands of Neendakara-Kayamkulam belt in Kerala, south India, is studied using advanced techniques and standardized methods. Beach sediments were collected and analyzed for the texture, and mineralogy reveals that the study area contains characteristically fine sand with maximum 98.9\% total heavy minerals (THM) content with ilmenite as predominant mineral species. The content of monazite ranges from 0.1 to $1.4 \%$. A combination of unit operations like gravity separation, magnetic separation and electrostatic separation techniques were applied to the beach sand to recover monazite mineral. The data indicate that samples show a maximum yield of about $81 \%$ for THM and $0.5 \%$ for monazite. The ED-XRF, XRD and SEM-EDS analysis gives reliable results on the chemistry of monazite. The major chemical constituents of monazite mineral like $\mathrm{Ce}_{2} \mathrm{O}_{3}, \mathrm{La}_{2} \mathrm{O}_{3}, \mathrm{P}_{2} \mathrm{O}_{5}$ corresponds to $26.658,13.421$ and $23.649 \%$, respectively. The SEM reveals the weathering mechanism, both mechanical and chemical, occurred in monazite mineral. Advanced characterization of monazite mineral will influence positively the efficiency of determining their potential applications.
\end{abstract}

Keywords Monazite $\cdot$ Heavy minerals $\cdot$ SEM-EDS $\cdot$ ED-XRF $\cdot$ India

\section{Introduction}

The beach sand mineral industry in India owes its growth to the discovery of monazite, a complex phosphate of rare earth elements [1]. Monazite occurs in the beach placer deposit along with other heavy minerals such as ilmenite, rutile, leucoxene, zircon, sillimanite, and garnet. The monazite is separated as a by-product of titanium minerals. The monazite, being the commercial ore of rare earth elements (REE), draws the attention of researchers interest all over the world [2]. The most important REE-bearing phosphate minerals like monazite and xenotime mostly occur in different magmatic and metamorphic rocks as an accessory or even rock-forming mineral and hence, be upgraded to form mineral deposits such as in some carbonatites $[3,4]$. The occurrence of monazite in beach sands causes radionuclide enrichment along the coast [5]. In Chavara-Neendakara area of Kerala state, India, the thoron exhalation rate was reported around 4-12 times higher than that of normal soil surfaces [6]. In Brazil, monazite-rich sands show a significant rise in thorium decay chain activities compared to other parts of the world [7]. The gamma spectral analysis shows that the presence of monazite and microcline feldspar are the primary source of ${ }^{232} \mathrm{Th}$ and ${ }^{40} \mathrm{~K}$ in the intertidal sand samples of Tamilnadu coast [8].

M. Sundararajan, rajanmsundar77@yahoo.com | ${ }^{1}$ Department of Environmental Sciences, University of Kerala, Kariavattom, Thiruvananthapuram, Kerala 695581, India. ${ }^{2}$ Minerals Section, Materials Science and Technology Division, CSIR-National Institute for Interdisciplinary Science and Technology (CSIR-NIIST), Thiruvananthapuram, Kerala 695019, India. 
In India, monazite is the only commercial source of rare earth elements. The group consists of yttrium and the 15 lanthanide elements viz., lanthanum, cerium, praseodymium, neodymium, etc. The uses of REE range greatly from the least sophisticated product such as a pair of sunglasses to highly advanced products such as nuclear reactors. A systematic study on the distribution and separation of monazite in various locations along the south-west coastal area of India and the geochemistry of monazite, its major, minor and trace elements, etc. are interesting fields of research, and these are mainly addressed in the present study. The presence of radio elements and rare earth elements were scientifically studied using advanced characterization techniques for the beach sands of Andhra Pradesh, eastern coast of India [9], beach black sand at north of Nile Delta, Egypt [10], southeastern US coastal plain [11]. Shrivastava et al. (2018) use HPGe semiconductor detector for studying the uranium content in Indian monazite samples [12]. Dating of beach monazites collected from Alleppey in Kerala clearly reveals the age of tectono-thermal history of Trivandrum block [13].

Grain size studies of beach sediments provide information on the intrinsic properties of sediments, and their depositional environment [14]. Several researchers, Chaudhari et al.(1981), Rajmanickam and Gujar (1993), Rao et al. (2005), Angusamy and Rajamanickam (2006), Gandhi et al. (2008), Ramathan et al.(2009), Gayathri et al. (2017), and Sajimol et al. (2017) carried out systematic granulometric, and heavy mineral studies of the east and west coasts of India [15-22]. Outside India also, many studies were conducted on mineralogy, chemistry, and provenance of beach minerals in South China Sea [23], Africa [24], Sri Lanka [25], Egypt [2], and Somaliland coastal areas [10]. Investigation on texture and mineralogy of beach sediments play a prime role in deriving the depositional history of beach regions [18]. Mineral processing is also an important area where immense research has been carried out for improving the efficiency in recovering the mineral in beach sands [26-28]. Since the monazite is magnetic and non-conducting in nature, a combination of magnetic, electrostatic, and gravity separation units can be successfully used for separating monazite mineral from beach sands [29]. Recovery of strategic minerals was successfully carried from red sediments of Badlands, Andhra Pradesh [30], beach sands of Thiruvananthapuram district [29], placer deposits of North Korea [31], etc.

The objective of the present study is to enlighten the chemistry and distribution of monazite mineral along the coast of Neendakara-Kayamkulam belt in Kerala, southwest coast of India. An attempt is made to investigate the texture and mineralogy of beach sediments followed by the recovery of monazite mineral for detailed structural and chemical characterization.

\section{Study area}

The study area, Chavara deposit, is a major beach placer deposit along the south-west coast of India. It occurs along the coastal area in Karunagapally Taluk of Kollam district, Kerala, comprising $22.5 \mathrm{~km}$ length extending from Neendakara $\left(8^{\circ} 56^{\prime} 03^{\prime \prime} \mathrm{N}\right.$ and $\left.76^{\circ} 32^{\prime} 34^{\prime \prime} \mathrm{E}\right)$ in the south to Kayamkulam ( $9^{\circ} 8^{\prime} 24^{\prime \prime} \mathrm{N}$ and $\left.76^{\circ} 27^{\prime} 36^{\prime \prime} \mathrm{E}\right)$ in the north, and width ranging from 200 to $300 \mathrm{~m}$. The study area of the south-western part of the Indian subcontinent is a significant portion of the Indian shield. The region comprises largely Precambrian crystallines such as charnockites, khondalites, and migmatitic gneisses. The beach sands occur in Neendakara-Kayamkulam belt (Fig. 1) is one of the best qualities in the world containing high-grade $\mathrm{TiO}_{2}$ in ilmenite. Along the belt, the ilmenites mostly exist, followed by other important minerals like monazite, sillimanite, zircon, rutile, etc. The existence of all these minerals along the coastal tract totally depends on provenance rocks, climate, coastal geomorphology, and drainage pattern. The wave action and currents act as the primary factor deciding the size of the grain, and also result in relative sorting of these heavy minerals [32].

Granulite facies rocks of south Kerala comprising khondalites and migmatites are assigned as the provenance rocks of the beach deposits [33, 34]. The various lithological units are clearly shown in the geology map of the study area (Fig. 2). The supply and enrichment of heavies on the beach face are related to wave processes [35]. The sand grains originated by the weathering action in the Western Ghats were carried down along the rivers to the sea and deposited along the coast. The highgrade metasediments of khondalite belt are responsible for high-Ti ilmenite [36]. The garnet and pyribole-free heavy mineral suits occurred along the coastal plain of Kollam are mainly derived from the denudation of Neogene sedimentary deposits formed during the rising sea level phases occurred in late quaternary periods [37]. The erosion of the heavy mineral-rich beach and the winnowing of the more easily entrained quartz sediments results in high concentration of heavy minerals [35].

\section{Materials and methods}

Detailed mineralogical analysis of raw sand collected from each location along the coastal strip has to be done to grade the deposit based on monazite content. The coast of Neendakara-Kayakulam belt is $22.5 \mathrm{~km}$ long and $200-300 \mathrm{~m}$ wide. The sample collection was done in 


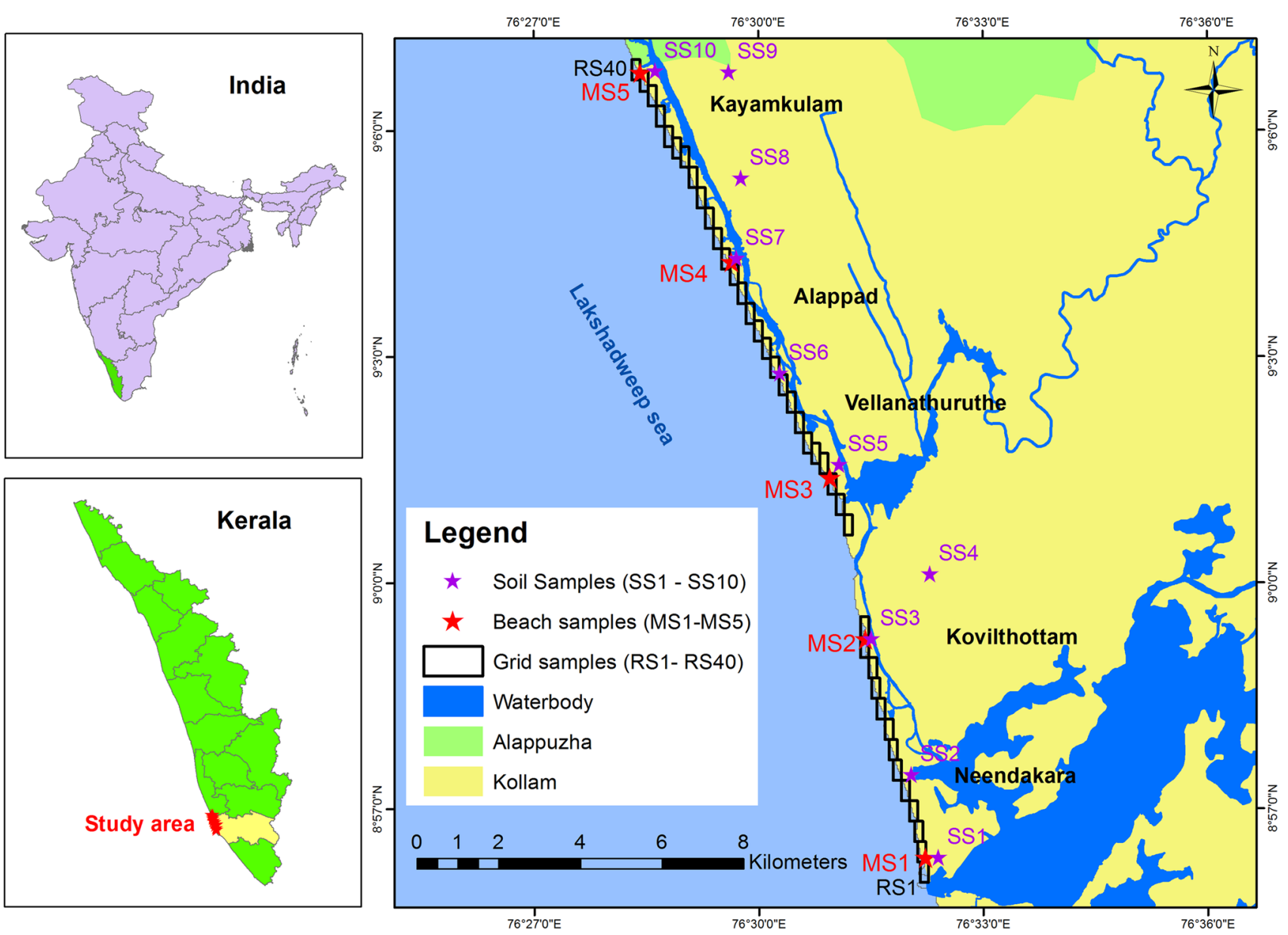

Fig. 1 Map of study area

three steps, (1) five beach sand samples (MS1-MS5) were collected to a depth of $100 \mathrm{~cm}$ from five sampling stations at an interval of $\sim 4 \mathrm{~km}$, (2) forty raw sand samples (RS1-RS40) were collected to a depth of $100 \mathrm{~cm}$ from the grids (grid size $=200 \mathrm{~m} \times 500 \mathrm{~m}$ ) along the coastal strip, and (3) ten soil samples (SS1-SS10) collected to a depth of $100 \mathrm{~cm}$ within $2 \mathrm{~km}$ buffer zone from the shoreline. All samples were subjected to detailed mineralogical analysis, but only the five beach samples (MS1 to MS5) were taken for textural analysis and recovery of monazite mineral. A representative composite sample of $100 \mathrm{~g}$ was taken for analysis after mixing the bulk sample thoroughly, the samples from all the segments were collected in polythene sample bags and labelled correctly in the same way and kept ready for analysis.

Mineralogical analysis to determine the per cent content has been done as per the procedure developed by the Atomic Minerals Directorate (AMD), Govt. of India, and the flow chart is shown (Fig. 3). At first, the samples were washed thoroughly with water to remove organic matter, slime, etc. and then with dil. $\mathrm{HCl}$ (1:1 by volume) to dissolve shells and shell fragments. The preprocessed sample is then sieved in a Ro-tap sieve shaker in different sieves, and the percentage of each sieve fraction is calculated. If magnetite is present in the samples, then, it was removed by using a hand magnet. The magnetite-free fractions were separated into magnetic and non-magnetic fractions with the help of a laboratory electromagnet. Ilmenite, garnet, and traces of monazite present were separated at a magnetic susceptibility around $0.3-0.4 \mathrm{~A}$. The non-magnetic portion contains rutile, zircon, monazite, leucoxene, and sillimanite along with quartz. The quartz was separated by a heavy media separation method using bromoform, which has a specific gravity of 2.89 [38]. The fractions are analyzed using a Leitz binocular-polarized microscope. The weight percentage of each mineral was computed from the total number of grains counted for each mineral [39]. Spatial distribution of total heavy minerals (THM) and monazite in the study area was also mapped using inverse distance weighted (IDW) interpolation technique available in the spatial analyst extension of ArcGIS software. GIS-based surface interpolation techniques incorporated 


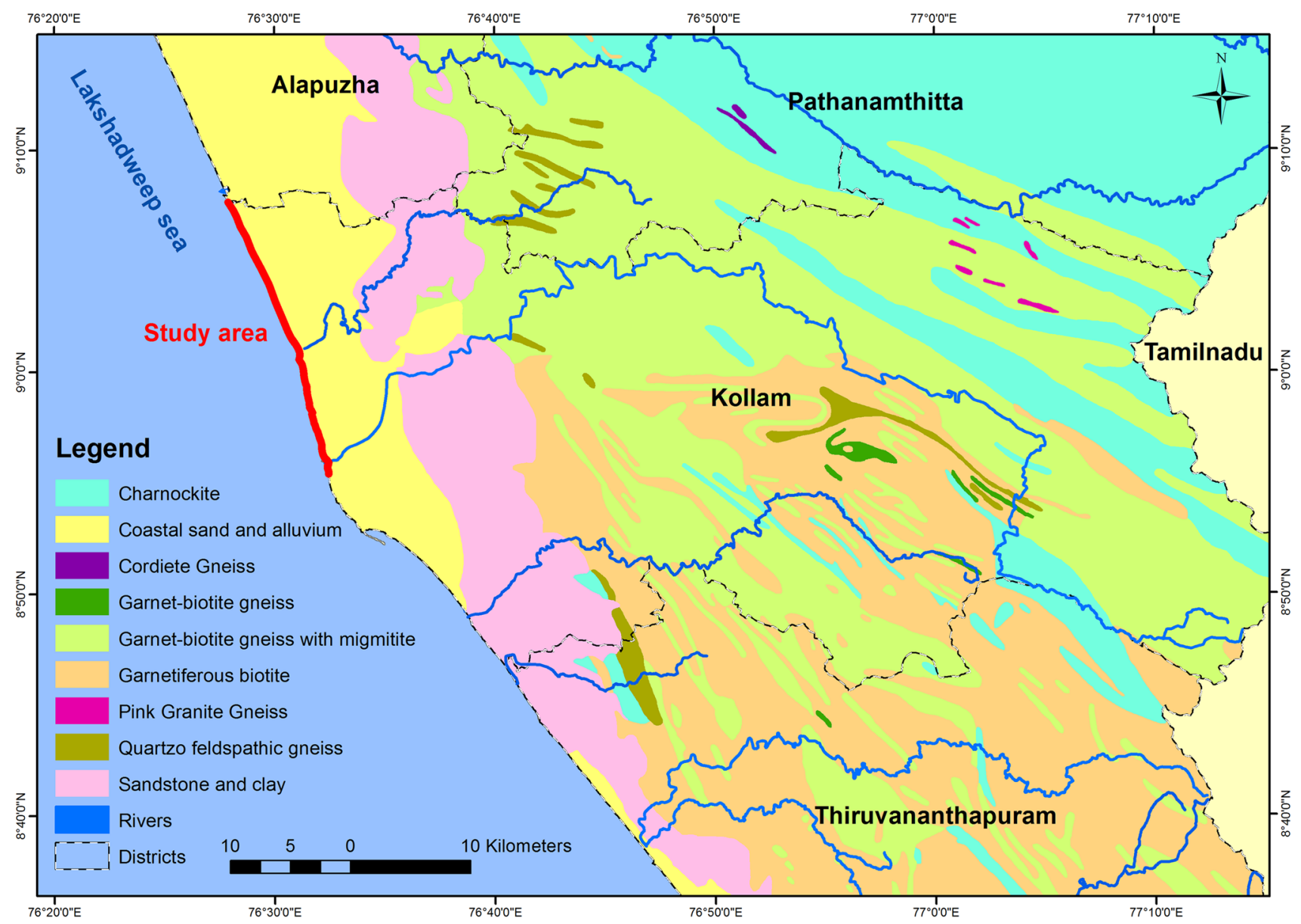

Fig. 2 Geology of the study area

in the spatial analyst tool of ArcGIS software produces surface maps showing spatial variability and continuity of data $[40,41]$. The grain size parameters like graphic mean (M), inclusive graphic standard deviation (SD), inclusive graphic skewness (SK), and graphic kurtosis (KU) were determined using the software package. The various graphic and moment measures were calculated with the formulae of [39]. The calculated statistical values were interpreted for Sahu's (1964) linear discriminate functions of $Y_{1}$ (Aeolian: Beach), $Y_{2}$ (Beach: Shallow agitated water), for analyzing the relationship of energy and the fluidity factors with different processes modes of sediment deposition and transportation [42].

The $Y_{1}$ and $Y_{2}$ were calculated from textural parameters using the Eqs. (1) and (2).

$$
\begin{aligned}
& Y_{1}(\text { Aeolian/Beach })=-3.5688 \mathrm{M}+3.7016 \mathrm{SD} \\
& -2.0766 \mathrm{SK}+3.1135 \mathrm{KU}
\end{aligned}
$$

If the value of $Y_{1}$ is $>-2.7411$, the environment is 'Beach' and if $Y_{1}<-2.7411$, then it corresponds to 'Aeolian' environment.

$$
\begin{aligned}
& \left.Y_{2} \text { (Beach/shallow agitated water }\right)=15.6534 \mathrm{M} \\
& +65.7091 \mathrm{SD}+18.1071 \mathrm{SK}+18.5043 \mathrm{KU}
\end{aligned}
$$

For $Y_{2}<63.3650$, the environment is 'Beach', and in case of $Y_{2}>63.3650$, the environment is 'Shallow marine'.

Where $M$ is graphic mean, $S D$ is inclusive graphic standard deviation, SK is inclusive graphic skewness, and KU is graphic kurtosis.

A combination of unit operations including magnetic, electrostatic, and gravity separation techniques was applied to the beach sediments collected from the five locations (MS1-MS5) for recovering the monazite mineral [29]. The selection of separation techniques depends upon the physical properties of monazite mineral such as magnetic susceptibility, electrical conductivity, and specific gravity [43]. The raw beach samples were sieved for removing larger pieces of stones, shells, etc. and fed into 


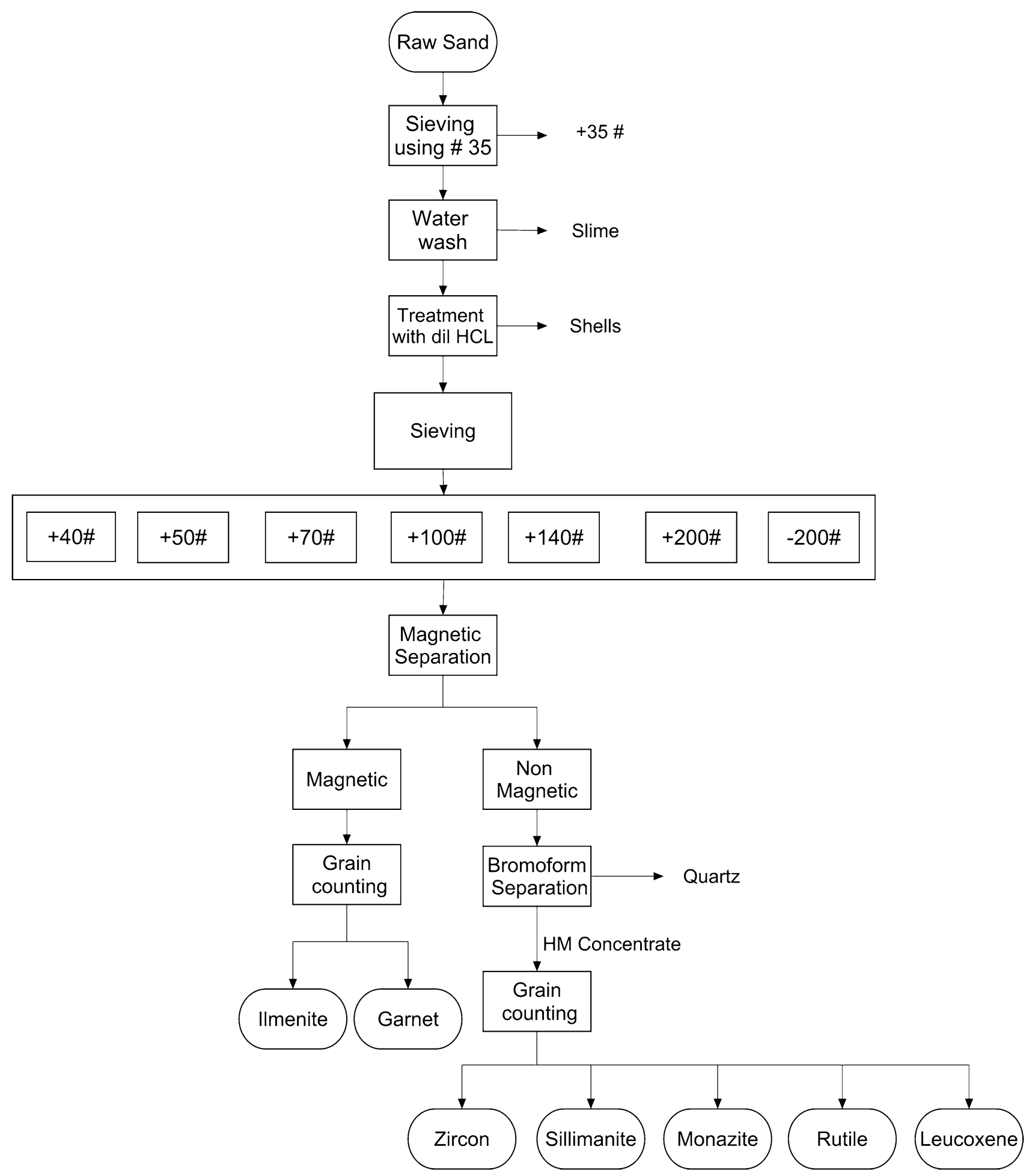

Fig. 3 Flow chart showing the heavy mineral analysis of beach sands

Mineral Technologies short spiral concentrator (laboratory model) for recovering heavy mineral concentrate [44]. The magnetic minerals such as ilmenite and garnet were removed using Carpco rare earth drum magnetic separator (laboratory model). The paramagnetic mineral such as ilmenite was selectively separated using high intensity dry magnetic separators [45-47]. The zircon and sillimanite were removed as non-conducting minerals using 
Orekinetics Corona Stat high tension separator (laboratory model) [48]. The non-magnetic rutile is removed by using Reading's induced roll magnetic separator (IRMS) (laboratory model), and non-conducting leucoxene is removed using Mineral Technologies electrostatic plate separator (laboratory model). The feed samples for the electrostatic separation are dried and heated to $110-180^{\circ} \mathrm{C}$ for removing the moisture $[43,49]$. Any changes in ambient conditions may cause poor separation of minerals [50]. Finally, the panning is done to recover monazite grains from ilmenite having low specific gravity. The S.G. Frantz isodynamic separator recovers high-grade monazite by removing all other impurities. The samples recovered at different stages during the process were analyzed under the microscope for identifying the minerals of interest. Flow sheet showing the recovery of monazite is shown in Fig. 4.

The $\mathrm{X}$-ray diffraction analysis of monazite mineral was conducted using PANalytical X'Pert Pro diffractometer, and results were processed using X'Pert High Score Plus software (PANalytical). Pan Analytical Epsilon 3 ED-XRF instrument with Omnion software (elemental range is $\mathrm{Mg}-\mathrm{U}$ ) is used for analyzing the bulk geochemistry of the recovered monazite and soil samples (SS1-SS10). The surface morphology of monazite grains was analyzed using scanning electron microscope (SEM) of JEOL make model JSM5600 LV. Energy dispersive X-ray spectroscopy (EDS) elemental analysis was also carried out using a Silicon Drift Detector-X-MaxN attached to the SEM of Carl Zeiss make EVO18 model.

\section{Results and discussion}

Detailed investigation on texture, distribution, composition, and rare earth chemistry of monazite mineral along the coastal sediments of Neendakara-Kayamkulam belt in Kerala, SW coast of India was carried out using systematic and scientific procedures.

\subsection{Textural studies}

Detailed and systematic studies on marine sediments made a breakthrough in deriving the relation between textural parameters and transportation process of sediments $[19,39,51]$. The textural parameters like mean, sorting, skewness, and kurtosis help to understand the nature of sediment deposition [18]. The descriptive statistics of textural parameters for five samples (MS1-MS5) are shown in Table 1. All the locations contain fine-grained sediments (size range $=2.6-2.7 p h i$ ) with sorting ranges from well sorted to moderately well sorted (range $=0.44-0.59 \mathrm{phi}$ ). Skewness reached coarse skewed, except for MS4, where it shows nearly symmetrical. The kurtosis for MS4 is

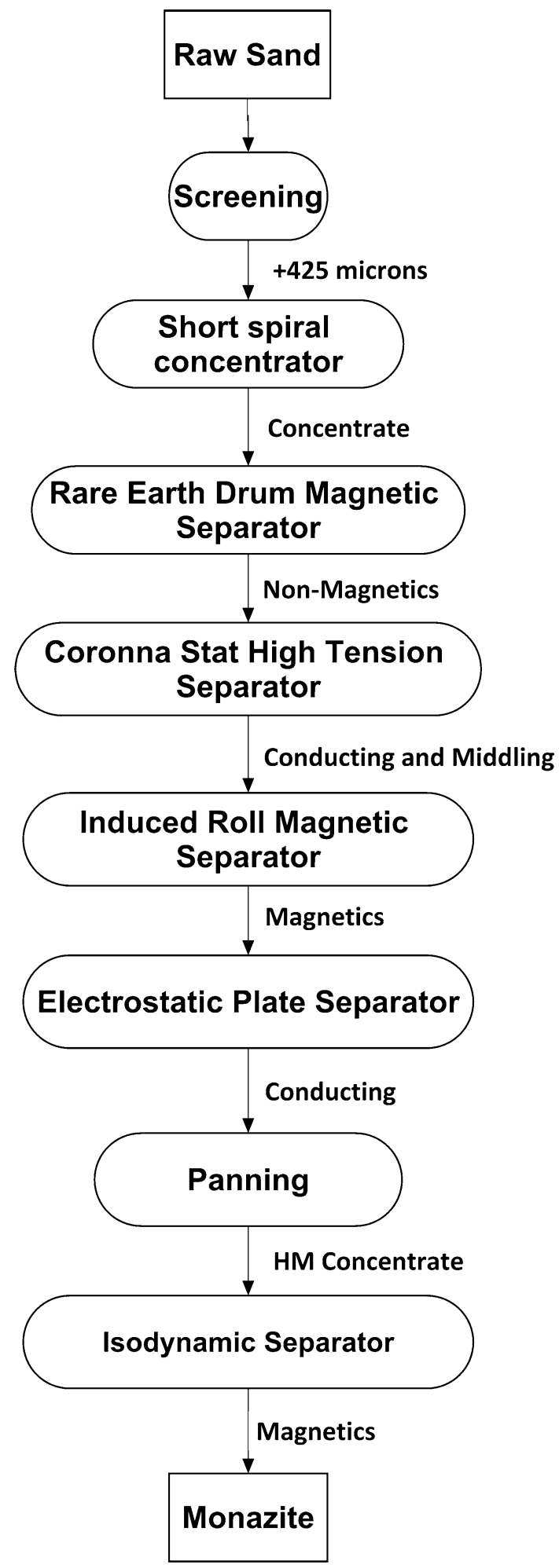

Fig. 4 Flow sheet showing the recovery of monazite from the beach sands

platykurtic, while others show mesokurtic. Large variations in the values of kurtosis show the flow characteristics of the medium of deposition, and also it indicates the 
Table 1 Statistical data on textural parameters of samples

\begin{tabular}{llllllllll}
\hline SI. no. & Sample ID & M (phi) & Remarks & SD (phi) & Remarks & SK & Remarks & KU Remarks \\
\hline 1 & MS1 & 2.6 & Fine & 0.58 & Moderately well sorted & -0.3 & Coarse skewed & 1 & Mesokurtic \\
2 & MS2 & 2.6 & Fine & 0.58 & Moderately well sorted & -0.3 & Coarse skewed & 1 & Mesokurtic \\
3 & MS3 & 2.7 & Fine & 0.49 & Well sorted & -0.2 & Coarse skewed & 1.1 & Mesokurtic \\
4 & MS4 & 2.7 & Fine & 0.44 & Well sorted & -0.1 & Nearly Symmetrical & 0.9 & Platykurtic \\
5 & MS5 & 2.6 & Fine & 0.59 & Moderately well sorted & -0.2 & Coarse skewed & 0.92 & Mesokurtic \\
\hline
\end{tabular}

M=Graphic Mean; SD = Graphic Standard Deviation; SK= Graphic Skewness; KU = Graphic Kurtosis

existence of a high energy environment which results in the sorting of sediments $[52,53]$. The location MS4 shows the dominance of finer size of sediments with platykurtic nature and highlights the maturity of sand, which is mainly due to the aggregation of sediment particle size by compaction. The variation in sorting values occurs due to the continuous deposition of finer or coarser-sized sediments in varying proportions [20].
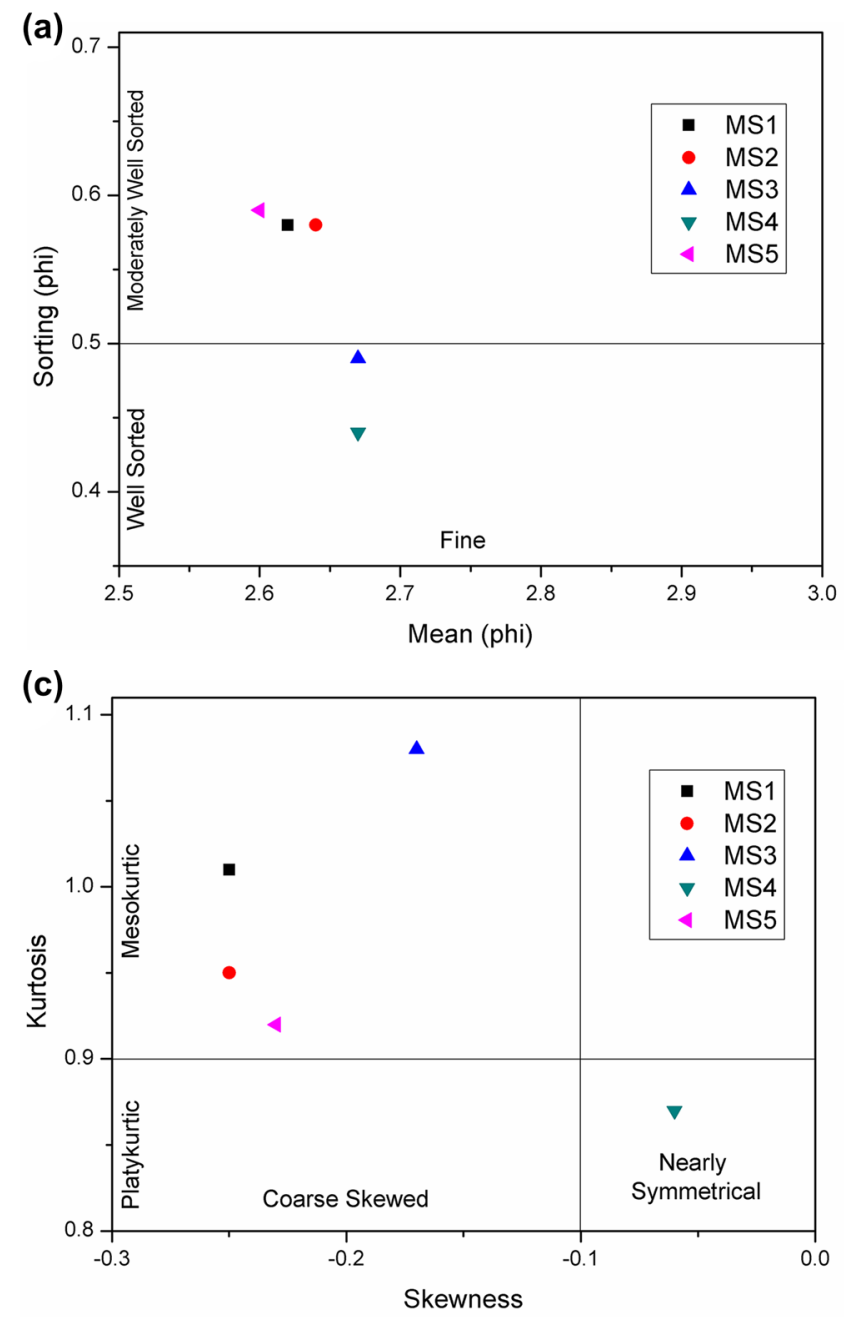

The bivariant plots are generated based on the relation between the textural parameters and fluid-flow mechanisms of sediment movement [54]. The Fig. 5a shows the relationship between mean grain size and sorting, Fig. $5 \mathrm{~b}$ shows the relationship between sorting and skewness and Fig. $5 \mathrm{~d}$ shows the relationship between skewness and kurtosis. In Fig. 5a, clustering can be seen in both fine-sized well-sorted and moderately well-sorted regions, which

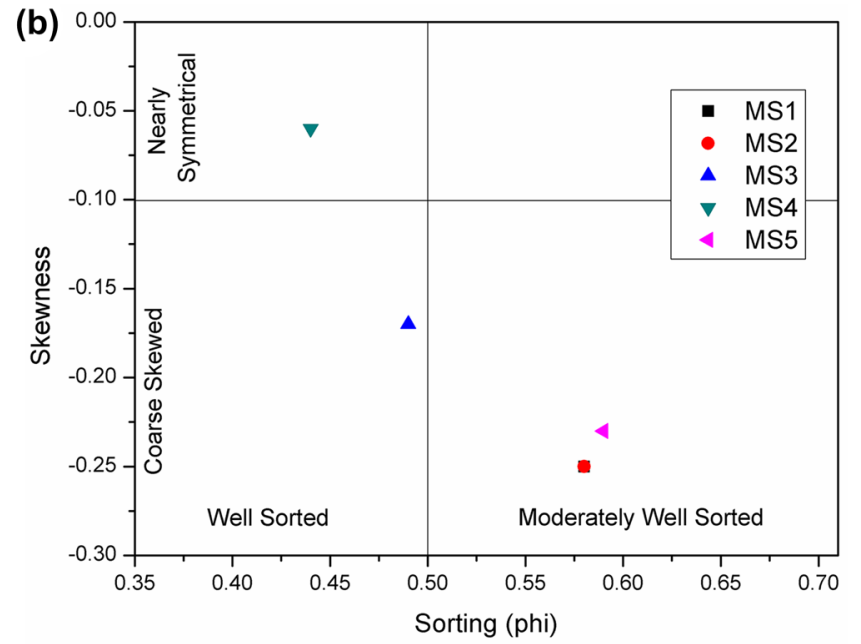

(d)

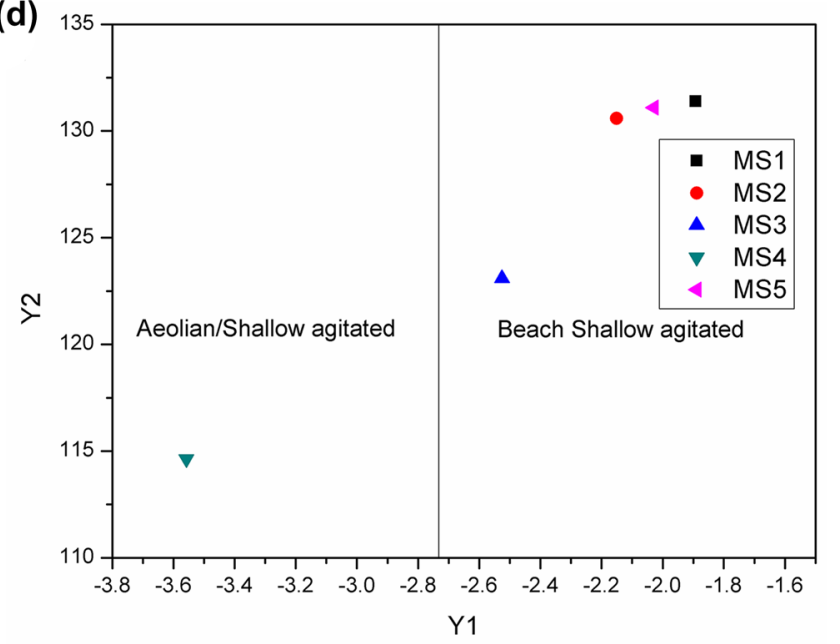

Fig. 5 Bivariant plots and LDF Curves. a Mean versus sorting b Sorting versus skewness c Skewness versus kurtosis $\mathbf{d} Y_{1}$ versus $Y_{2}$ 
indicates the best sorting of sediments. Since the mean size and sorting are hydraulically controlled, the best sorting can be only seen in sedimentary environments having fine-sized grains [55]. Only one well-sorted fine-sized region falls under near symmetrical range with negative skewness and platykurtic range. In contrast, all other regions fall under coarse skewed and mesokurtic range. Folk (1966) showed that a small proportion of coarser grains leads to a slightly negatively skewed sedimentary environment [56]. Rajaganapathi et al. (2013) showed that for a predominant population of medium sands, subordinate coarser grains leads to negative skewness and fine leads to positive skewness [14]. Thus, it can be concluded that the beach sediments of the study area mainly consist of fine-sized grains as the predominant population with

Table 2 Linear discriminate function (LDF) values

\begin{tabular}{|c|c|c|c|c|}
\hline Sample ID & $Y_{1}$ & Remarks & $Y_{2}$ & Remarks \\
\hline MS1 & -1.892615 & Beach & 131.39703 & $\begin{array}{l}\text { Shallow marine } \\
\text { agitated }\end{array}$ \\
\hline MS2 & -2.150801 & Beach & 130.59984 & $\begin{array}{l}\text { Shallow marine } \\
\text { agitated }\end{array}$ \\
\hline MS3 & -2.525526 & Beach & 123.09593 & $\begin{array}{l}\text { Shallow marine } \\
\text { agitated }\end{array}$ \\
\hline MS4 & -3.557947 & Aeolian & 114.6309 & $\begin{array}{l}\text { Shallow marine } \\
\text { agitated }\end{array}$ \\
\hline MS5 & -2.028954 & Beach & 131.0949 & $\begin{array}{l}\text { Shallow marine } \\
\text { agitated }\end{array}$ \\
\hline
\end{tabular}

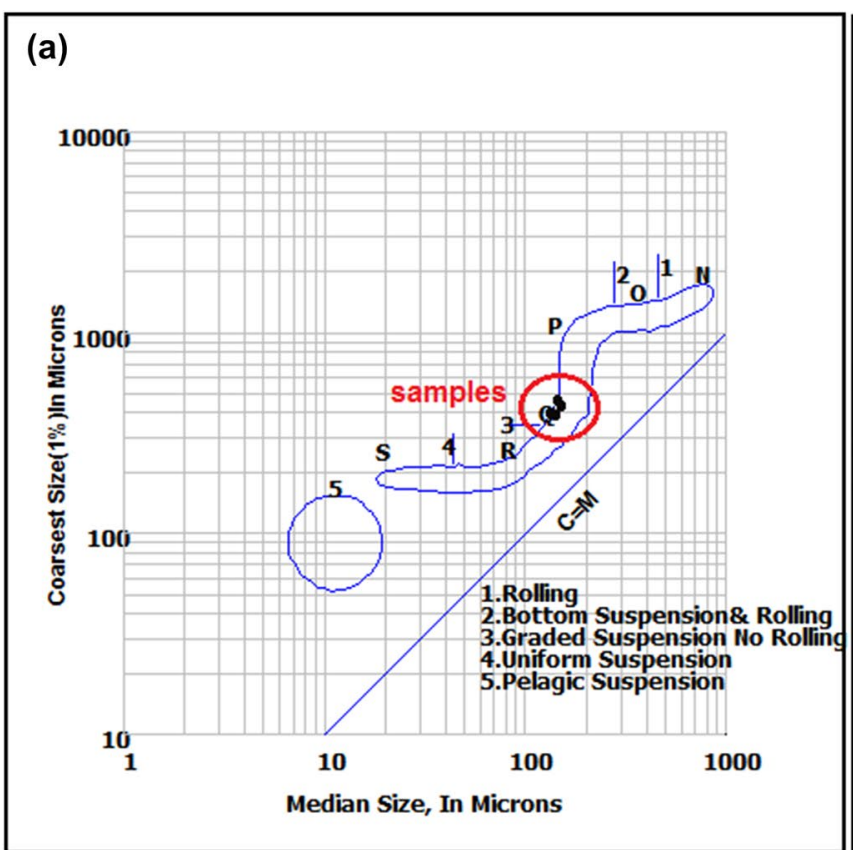

subordinates of medium grains, which leads to negative skewness ranges from meso to platykurtic.

The process and environment of deposition of sediments have an excellent correlation with the variations in the energy of waves and fluidity factors. Sahu (1964) uses a statistical method of linear discriminate function (LDF) analysis for interpreting these variations [42]. The results of the LDF calculation are shown in Table 2. The Fig. $5 \mathrm{~d}$ shows the relationship between $Y_{1}$ and $Y_{2}$. With reference to the values of $Y_{1}$ and $Y_{2}$, all samples fall in beach shallow marine agitated water except MS4, which falls in Aeolian shallow marine agitated water. The different modes of deposition of sediments can be easily found out using CM pattern $[57,58]$. The $C M$ pattern is obtained by plotting the micron values of the parameters $C$ (one percentile of the grain size distribution) against $M$ (the median), as shown in Fig. 6 . The CM pattern has been divided into different segments, namely NO (rolling), OPQ (bottom suspension androlling), QR (graded suspension no rolling), RS (uniformsuspension), and S (pelagic suspension). All the samples of study area fall in bottom suspension rolling. On comparing with the TCD diagram shown in Fig. $6 \mathrm{~b}$, the samples fall in the tractive current environment due to their interaction with wave actions. During monsoon, waves are characterized at higher heights and shorter periods with the direction being more westerly but the premonsoon and postmonsoon waves are dominated towards southerly direction at lower heights and higher periods [59]. (b)

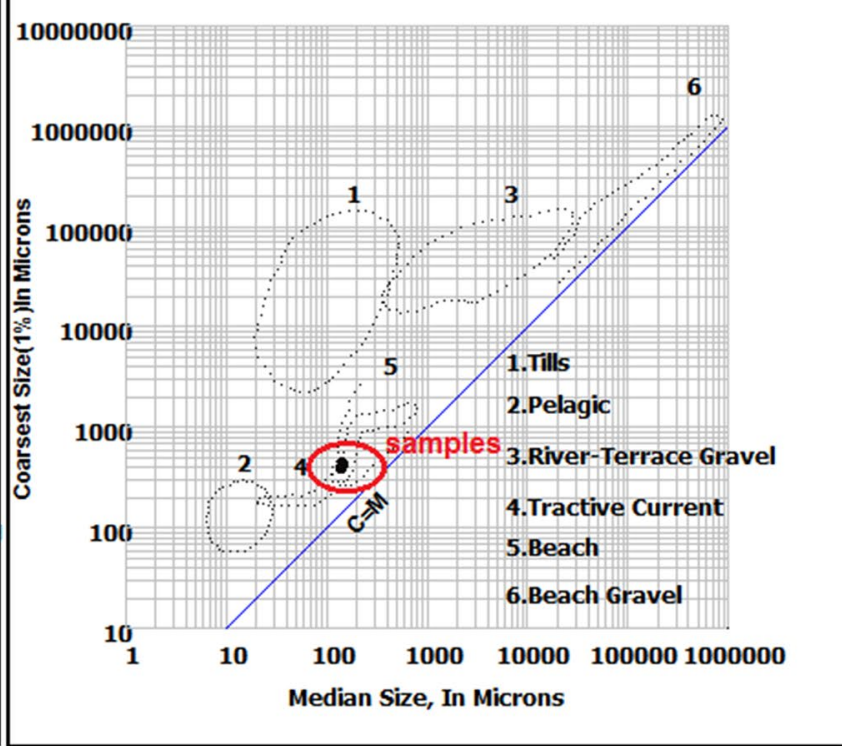

Fig. 6 CM and TCD diagrams. a CM diagram b TCD diagram 


\subsection{Heavy mineral analysis}

High energy waves are required for the transportation and concentration of heavy minerals compared to light minerals due to their high specific gravity [14]. The type of weathering, mode and distance of transportation, and the nature of the depositional environment are closely related to the occurrence of heavy minerals [60]. The total heavy mineral weight percentage derived from the bromoform analysis helps to evaluate the mineral resource of the study area and also depicts a clear picture of the nature of the source from which these strategic minerals are derived.

Tables 3, 4 and Fig. 7 show the results of heavy mineral analysis carried out for beach sediments (MS1-MS5), soil samples (SS1-SS10), and grid samples (RS1-RS40) collected from the study area. The total heavy mineral weight percentage (THM \%) is maximum for the sample location MS4 (79.5\%), followed by MS3 (68.2\%), MS5 (55\%), MS2 (34.4\%), and MS1 (18.1\%) in the decreasing order of abundance. The percentage content of heavy minerals is high in areas from Karithura to Vellanathuruthu. The results of grain counting shows that ilmenite is dominant with a maximum of about $58.2 \%$, followed by sillimanite (10.8\%), zircon $(5.8 \%)$, rutile $(4.2 \%)$, monazite $(0.9 \%)$, leucoxene $(0.6 \%)$, and garnet $(0.2 \%)$ in the decreasing order of abundance. Others, such as pyroxenes and amphiboles, were also present to a maximum of $0.6 \%$. The concentration of ilmenite mineral varies with the locations in the order of MS4 $>$ MS3 $>$ MS5 $>$ MS2 > MS1 and that of monazite mineral is MS3 $>$ MS4 $>$ MS5 $>$ MS2 $>$ MS1. The high concentrations of minerals, especially that of ilmenite and monazite, are seen in locations MS3 to MS5. The concentration of heavy minerals in the samples varies from 13 to $84.4 \%$.

The results of mineralogical analysis (Fig. 7) for the bulk sediment show that ilmenite is the most abundant heavy mineral in all the 40 samples studied. The content of ilmenite ranges from 6.7 (RS10) to $60.5 \mathrm{wt} \%$ (RS 40) with an average value of $35.6 \mathrm{wt} \%$. This is followed by sillimanite (averageis 9.0, value ranges from 2.6 (RS8) to 13.5 (RS20), zircon (average is 5.2, value ranges from 1.7 (RS8) to 8.6 (RS 20), rutile (average is 3.0, value ranges from 0.9 (RS8) to 4.4 (RS 20), monazite (average is 0.6 , value ranges from 0.1 (RS5) to 1.2 (RS 28), and garnet (averageis 0.2 , value ranges from 0.1 to 0.4 ) in the decreasing order of abundance. Similarly,
Table 3 Heavy mineral count percentages of the beach samples (MS1-MS5)

\begin{tabular}{llllllllll}
\hline Sample & Ilmenite & Garnet & Rutile & Leucoxene & Monazite & Zircon & Sillimanite & Others & Total heavies \\
\hline MS1 & 10.1 & 0.1 & 1.6 & 0.2 & 0.1 & 2.2 & 3.6 & 0.2 & 18.1 \\
MS2 & 20.5 & 0.2 & 2.3 & 0.3 & 0.4 & 4.5 & 5.8 & 0.4 & 34.4 \\
MS3 & 46.2 & 0.2 & 3.8 & 0.5 & 0.9 & 5.2 & 10.8 & 0.6 & 68.2 \\
MS4 & 58.2 & 0.2 & 4.2 & 0.6 & 0.7 & 5.8 & 9.2 & 0.6 & 79.5 \\
MS5 & 36.4 & 0.2 & 3.2 & 0.3 & 0.5 & 5.1 & 8.8 & 0.5 & 55.0 \\
Max. & 58.2 & 0.2 & 4.2 & 0.6 & 0.9 & 5.8 & 10.8 & 0.6 & 81.3 \\
Min. & 10.1 & 0.1 & 1.6 & 0.2 & 0.1 & 2.2 & 3.6 & 0.2 & 18.1 \\
Avg. & 34.28 & 0.18 & 3.02 & 0.38 & 0.52 & 4.56 & 7.64 & 0.46 & 51.04 \\
\hline
\end{tabular}

Table 4 Heavy mineral count percentages of the soil samples (SS1-SS10)

\begin{tabular}{|c|c|c|c|c|c|c|c|c|c|c|}
\hline Sample ID & Ilmenite & Garnet & Rutile & Leucoxene & Monazite & Zircon & Sillimanite & $\begin{array}{l}\text { Other } \\
\text { minerals }\end{array}$ & Shell + Quartz & Total heavies \\
\hline SS1 & 20.6 & 0.2 & 2.2 & 1.5 & 0.4 & 3.4 & 5.3 & 0.6 & 65.8 & 34.2 \\
\hline SS2 & 8.3 & 0.1 & 0.7 & 0.6 & 0.5 & 1.6 & 5.5 & 0.2 & 82.5 & 17.5 \\
\hline SS3 & 63.3 & 0.2 & 4.5 & 1.4 & 1.4 & 10.4 & 5.0 & 0.7 & 13.1 & 86.9 \\
\hline SS4 & 5.8 & 0.3 & 1.6 & 0.3 & 0.2 & 2.6 & 5.7 & 0.8 & 82.7 & 17.3 \\
\hline SS5 & 42.5 & 0.2 & 1.9 & 1.5 & 0.4 & 1.7 & 5.1 & 0.5 & 46.2 & 53.8 \\
\hline SS6 & 21.2 & 0.1 & 1.3 & 0.6 & 0.3 & 2.1 & 4.1 & 0.2 & 70.1 & 29.9 \\
\hline SS7 & 77.6 & 0.2 & 5.2 & 0.9 & 1.1 & 10.9 & 2.8 & 0.2 & 1.1 & 98.9 \\
\hline SS8 & 5.4 & 0.1 & 0.9 & 0.7 & 0.7 & 4.1 & 5.2 & 0.5 & 82.4 & 17.6 \\
\hline SS9 & 12.4 & 0.1 & 1.2 & 0.4 & 0.1 & 0.8 & 3.1 & 0.2 & 81.7 & 18.3 \\
\hline SS10 & 16.4 & 0.2 & 1.8 & 0.8 & 0.6 & 3.5 & 5.8 & 0.4 & 70.5 & 29.5 \\
\hline Max. & 77.6 & 0.3 & 5.2 & 1.5 & 1.4 & 10.9 & 5.8 & 0.8 & 82.7 & 98.9 \\
\hline Min. & 5.4 & 0.1 & 0.7 & 0.3 & 0.1 & 0.8 & 2.8 & 0.2 & 1.1 & 17.3 \\
\hline Avg. & 27.4 & 0.2 & 2.1 & 0.9 & 0.6 & 4.1 & 4.8 & 0.4 & 59.6 & 40.4 \\
\hline
\end{tabular}




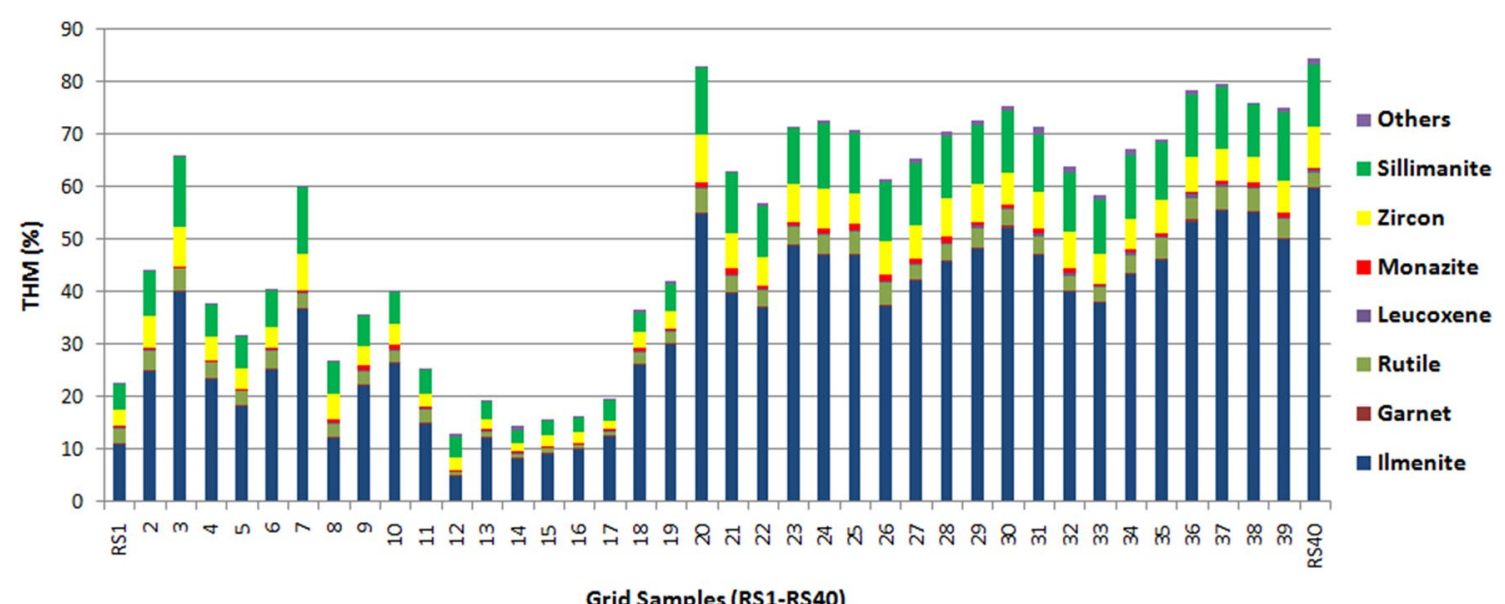

Fig. 7 Graph showing the results of heavy mineral analysis carried out for grid samples (RS1-RS40)

the total heavy minerals (THM) ranges from 14.5 (RS 10) to 85.1 (RS 40), with an average value of $54.5 \mathrm{wt} \%$. Among the total 40 stations, RS 40 shows the highest content of THM.

The THM \% in sediment samples varies from 17.3\% (SS 4) to $98.9 \%$ (SS 7), and the major constituent mineral, ilmenite, varies from $5.4 \%$ (SS 8) to $77.6 \%$ (SS 7) followed by sillimanite [varies from $2.8 \%$ (SS 7) to 5.8 (SS 10)], zircon [varies from to $0.8 \%$ (SS 9) to $10.9 \%$ (SS 7)], rutile, monazite, leucoxene, and garnet. The sample SS7 is located very near to the coastline at Alappad, whereas sample SS4 is located about $3 \mathrm{~km}$ away from the coastline, which clearly depicts the deposition of heavy minerals, including monazite, at a distance of $3 \mathrm{~km}$ from the coastline.

The heavy mineral distribution map, as shown in Fig. 8a, interpolated using the results of the heavy mineral analysis, also conveys the same. Maximum concentration is noticed around the Alappad region, and it gradually decreases in Kovilthottam and Neendakara regions. Figure $8 \mathrm{~b}$ shows the distribution of monazite mineral. The concentration of monazite is also maximum around the Alappad and gradually decreases towards the south side of Neendakara. While comparing with other regions, the concentration of heavy minerals was maximum around the coastal side as well as the inland area of the Alappad region.

From the study, it is found that a gradual decrease in heavy mineral concentration is found from the north towards the south of the study area and is due to the fact the central towards the southern part of the study area (Kovilthottam) is either a mined-out area or active mining area which shows comparatively less content because of the mining process. Maximum concentration is noticed around the Alappad (RS 22-24)-Azheekkal (RS 35-40) region, and it gradually decreases in Kovilthottam (RS 12-13)-Neendakara(RS 1) regions. As per the exploration study by AMD, up to a depth of $7.5 \mathrm{~m}$ in the study area indicated an average total heavy mineral (THM) content of $45 \mathrm{wt} \%$, with ilmenite $-35 \mathrm{wt} \%$, sillimanite- 7 , rutile-2.5, zircon-2.5, and monazite- 0.5 wt\% [61]. However, in the present study, up to $1 \mathrm{~m}$ depth shows an average HM content of $54.5 \mathrm{wt} \%$, and this indicates that the grade of deposit decreases with increasing depth. The studies by Krishnan et al. (2001) revealed that the high-grade placer deposits are seen from the surface up to a depth of $1.52 \mathrm{~m}$, with THM value varies from 73 to $91 \%$ [32]. The first report available on the mineral analysis of Neendakara-Kayamkulam placer deposit was that of the analysis conducted during 1935-39 [62], which shows that the heavy mineral content in the beach sand from north to south of study area during the 1930s were high with similar content. On comparing these with the present study for seven locations (i.e., Alappad, Cheriazheekkal, Pandarathuruth, Ponmana, Karithura, Parimanam, and Neendakara) covering the study area revealed that the content of ilmenite was high in the past, and it got reduced to low abundance recently. However, other minerals like rutile, zircon, sillimanite, and monazite show fluctuating trend, and their high content in some region is due to the dumping of leftovers (tailings) of earlier mining activities which take only ilmenite and monazite.

\subsection{Recovery of monazite}

Table 5 shows the recovery of monazite mineral from five sample locations (MS1-MS5). The data indicate that the samples MS3 and MS4 collected from Vellanathuruthe and Alappad shows a maximum yield of monazite mineral of about $0.574 \%$ and $0.500 \%$. The least recovery of monazite is from MS1 collected around the Neendakara. Altogether, $1.37 \%$ of monazite was successfully recovered from $45 \mathrm{~kg}$ 


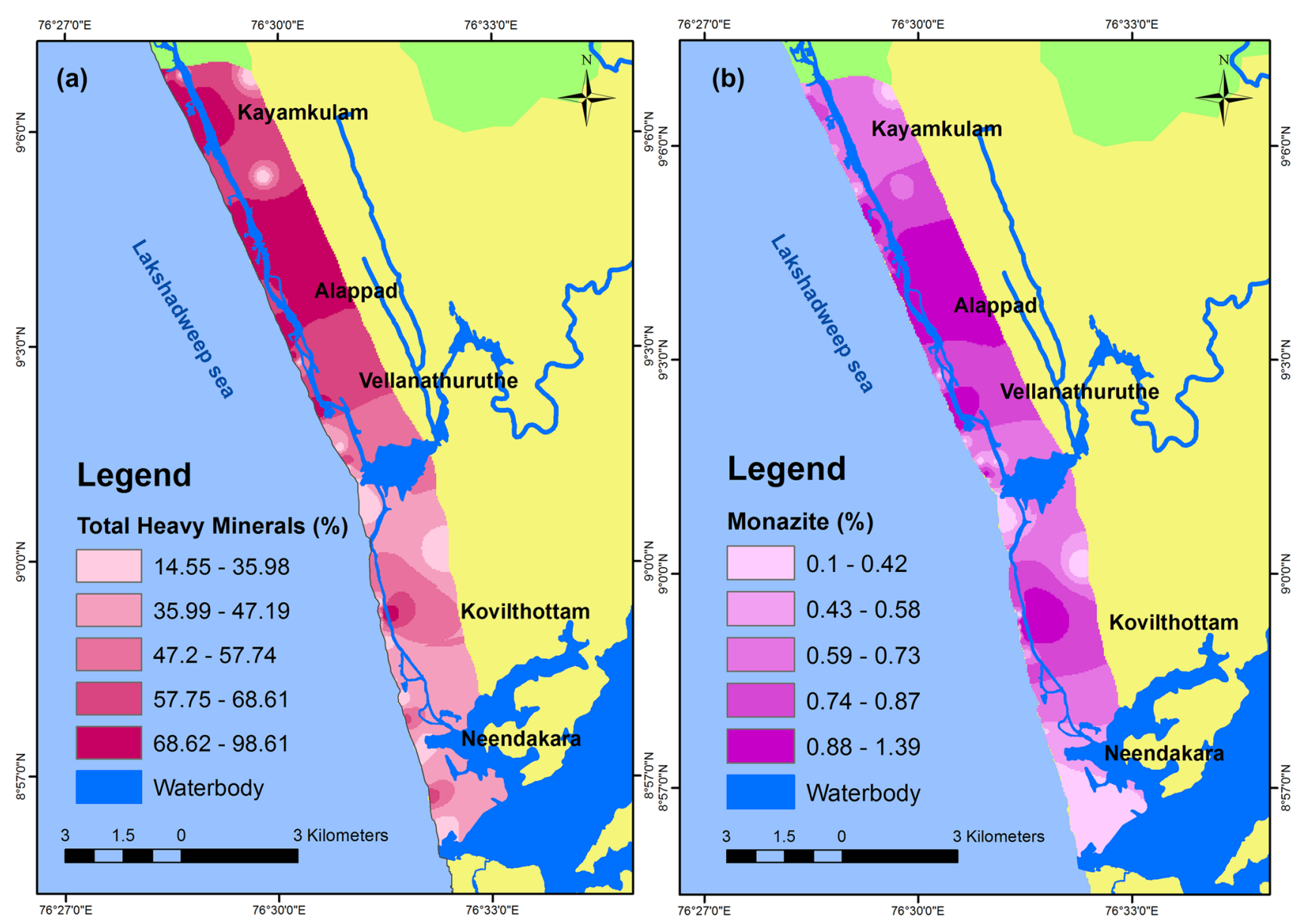

Fig. 8 Map showing the distribution of THM (a) and Monazite (b)

Table 5 Recovery of monazite from the beach sediments

\begin{tabular}{|c|c|c|c|c|c|}
\hline \multirow[t]{2}{*}{ Recovery of monazite } & \multicolumn{5}{|c|}{ Yield (\%) } \\
\hline & MS1 & MS2 & MS3 & MS4 & MS5 \\
\hline Raw sand (+ 425 microns sieving) & 90.62 & 94.30 & 97.39 & 94.47 & 88.79 \\
\hline Concentrate (short spiral concentrator) & 40.13 & 14.56 & 37.90 & 81.73 & 60.52 \\
\hline Non-magnetics (Rare earth drum magnetic separator) & 15.89 & 9.37 & 22.36 & 25.33 & 18.94 \\
\hline Conducting and middling (Coronna Stat high tension separator) & 9.80 & 4.92 & 7.60 & 13.80 & 12.19 \\
\hline Magnetics (Induced roll magnetic separator) & 0.188 & 0.347 & 1.273 & 0.982 & 0.387 \\
\hline Conducting (Electrostatic plate separator) & 0.076 & 0.200 & 0.784 & 0.646 & 0.219 \\
\hline HM Concentrate (Panning) & 0.056 & 0.136 & 0.661 & 0.556 & 0.182 \\
\hline Magnetic (Isodyamic Separator) & 0.028 & 0.106 & 0.574 & 0.500 & 0.157 \\
\hline
\end{tabular}

of raw sand collected from the study area. The successful separation of minerals was achieved based on the difference in specific gravity, electrostatic, and magnetic properties [43]. The XRD peak obtained for the recovered mineral is shown in Fig. 9. The XRD analysis of recovered mineral shows significant diffraction peaks of $\mathrm{LaPO}_{4}$, $\mathrm{CePO}_{4}, \mathrm{NdPO}_{4}, \mathrm{PmPO}_{4}, \mathrm{GdPO}_{4}$, and $\mathrm{P}_{2} \mathrm{O}_{5}$, and thereby it confirms that of monazite mineral [63].

\subsection{Geochemistry of monazite}

The chemical composition of the monazite mineral determined using ED-XRF is given in Table 6. The major chemical constituents of monazite mineral like $\mathrm{Ce}_{2} \mathrm{O}_{3}, \mathrm{La}_{2} \mathrm{O}_{3}$, and $\mathrm{P}_{2} \mathrm{O}_{5}$ corresponds to $26.658,13.421$, and $23.649 \%$, respectively. The radioactive content includes $\mathrm{U}$ and $\mathrm{ThO}_{2}$, which corresponds to $0.572 \%$ and $10.491 \%$. The major constituents present in the mineral are in order of $\mathrm{Ce}_{2} \mathrm{O}_{3}>\mathrm{P}_{2} \mathrm{O}_{5}$ 


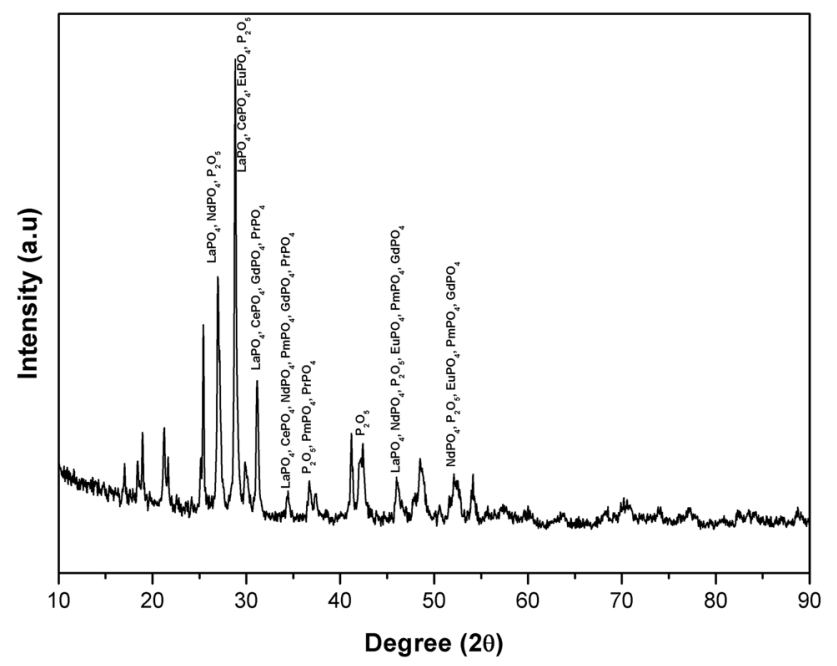

Fig. 9 XRD of monazite mineral

Table 6 Chemical composition of monazite using ED-XRF

\begin{tabular}{lc}
\hline Compound & Conc. \\
\hline $\mathrm{Ce}_{2} \mathrm{O}_{3}(\%)$ & 26.658 \\
$\mathrm{P}_{2} \mathrm{O}_{5}(\%)$ & 23.649 \\
$\mathrm{La}_{2} \mathrm{O}_{3}(\%)$ & 13.421 \\
$\mathrm{Nd}_{2} \mathrm{O}_{3}(\%)$ & 11.247 \\
$\mathrm{ThO}_{2}(\%)$ & 10.491 \\
$\mathrm{TiO}^{2}(\%)$ & 2.85 \\
$\mathrm{SiO} 2(\%)$ & 2.273 \\
$\mathrm{Pr} 2 \mathrm{O} 3(\%)$ & 2.264 \\
$\mathrm{CaO}(\%)$ & 1.481 \\
$\mathrm{Al}_{2} \mathrm{O}_{3}(\%)$ & 0.972 \\
$\mathrm{Sm} \mathrm{O}_{3}(\%)$ & 0.71 \\
$\mathrm{CdO}(\%)$ & 0.603 \\
$\mathrm{U}(\%)$ & 0.572 \\
$\mathrm{Fe} 2 \mathrm{O} 3(\%)$ & 0.527 \\
$\mathrm{Y} 2 \mathrm{O} 3(\%)$ & 0.399 \\
$\mathrm{PbO}(\%)$ & 0.286 \\
$\mathrm{MgO}(\%)$ & 0.233 \\
$\mathrm{ZnO}(\mathrm{ppm})$ & 489.8 \\
$\mathrm{IrO} 2(\mathrm{ppm})$ & 53.3 \\
$\mathrm{Gd} 2 \mathrm{O} 3 \mathrm{ppm})$ & 31.1 \\
$\mathrm{Re}(\mathrm{ppm})$ & 11.7 \\
\hline
\end{tabular}

$>\mathrm{La}_{2} \mathrm{O}_{3}>\mathrm{Nd}_{2} \mathrm{O}_{3}>\mathrm{ThO}_{2}>\mathrm{TiO}_{2}>\mathrm{SiO}_{2}>\mathrm{Pr}_{2} \mathrm{O}_{3}>\mathrm{CaO}>\mathrm{Al}_{2} \mathrm{O}_{3}$ $>\mathrm{Sm}_{2} \mathrm{O}_{3}>\mathrm{CdO}>\mathrm{U}>\mathrm{Fe}_{2} \mathrm{O}_{3}>\mathrm{Y}_{2} \mathrm{O}_{3}>\mathrm{PbO}>\mathrm{MgO}$. ZnO, $\mathrm{IrO}_{2}$, $\mathrm{Gd}_{2} \mathrm{O}_{3}$, and $\mathrm{Re}$ are also seen in ppm-level. The values show a strong agreement with the reported values using other geochemical characterization techniques [64]. In the present work, monazite grains were separated from the mineral assemblage using physical separation methods, and hence, the concentrate obtained is $99.9 \%$ monazite. The $0.1 \%$ may contain other magnetic minerals like ilmenite and leucoxene, since the monazite shows feebly magnetic property and may entrap some other grains also in the concentrate, which is the reason for the contamination. The presence of $\mathrm{TiO}_{2}, \mathrm{FeO}, \mathrm{CdO}, \mathrm{ZnO}, \mathrm{Ir}$, and Re shows the contamination of very less amount of ilmenite and rutile minerals. The silicates show the presence of silliminate and kyanite. These XRF values may help to analyze the possible contamination occurred to monazite minerals. In the same manner, the bulk chemical composition using XRF helps to analyze the contaminants in Malaysian monazite [65], Egyptian monazite [66], etc.

On analyzing the monazite from Chavara and Manavalakurichi using ICP-AES and ICP-MS, Jeya et al. 2008 proposed that La content varies from 9.73 to $12.04 \%, \mathrm{Ce}$ varies from 23.23 to $27.68 \%$, and that of $\mathrm{ThO}_{2}$ and $\mathrm{U}_{3} \mathrm{O}_{8}$ is $10.50 \%$ and $0.04 \%$ [64]. The total REE contents (TREE) ranges from 56.6 to $48.4 \%$ in which the light lanthanides (LREE) is 55.6 to $46.8 \%$, and the heavy lanthanides (HREE) is $1.55-0.908 \%$. The reported values of Th, $\mathrm{U}, \mathrm{Ce}$, and other rare earths obtained from ED-XRF show good agreement with the results of Jeya et al. (2008) [64]. On comparing with other states like Bhimunipatnam-Konada coastin Andhra Pradesh, India, Bangaku et al. (2016) reported that $\mathrm{ThO}_{2}$ content varies from 3.78 to $13.39 \%$, the REE ranges from 43.47 to $67.78 \%$ in which the LREE varies from 42.90 to $64.08 \%$, while HREE varies from 0.57 to $3.70 \%$ [67]. It was proved that monazite chemical composition can be used as proxy of provenance and source rock type $[68,69]$. The variation in rare earth, Th, and $U$ content is due to the presence of rocks act as provenance for heavy minerals, particularly monazite mineral. It was reported that the thorium shows a considerable variation in charnockites when compared with Khondalites of Eastern Ghats [70, 71].

The monazite mineral along with zircon usually seen as an accessory mineral in the granitic, meta-aluminous to para-aluminous granitoid rocks and in peliticschists and gneisses and rarely in sedimentary rocks [72]. The geochronological studies such as ${ }^{207} \mathrm{~Pb} /{ }^{206} \mathrm{~Pb}$ (radiogenic) confirmed that monazite from Chavara region in Kolam, Kerala, vary from 462 to $790 \mathrm{Ma}$, demonstrating the evidences of Pan-African event. The Sm-Nd (TDM) model ages clearly shows their provenances with protolith ages which varies from 2074 to $2242 \mathrm{Ma}$. On comparing with monazite mineral collected from Kanyakumari coast in India, the combined EPMA and $\mathrm{Sm}-\mathrm{Nd}$ isotope studies show tectono-thermal evolution of provenance and crustal accretionary processes [73]. The geochronlogical studies carried out on monazite and zircon confirms the provenance beach placer minerals as hinterland granulites belongs to Southern Granulite Segment (Trivandrum Block). Perumalsamy (2015) found the $\varepsilon_{\mathrm{Nd}}$ values of monazites from the southern Kerala about $550 \mathrm{Ma}(-14.6$ to -28.1$)$ which 

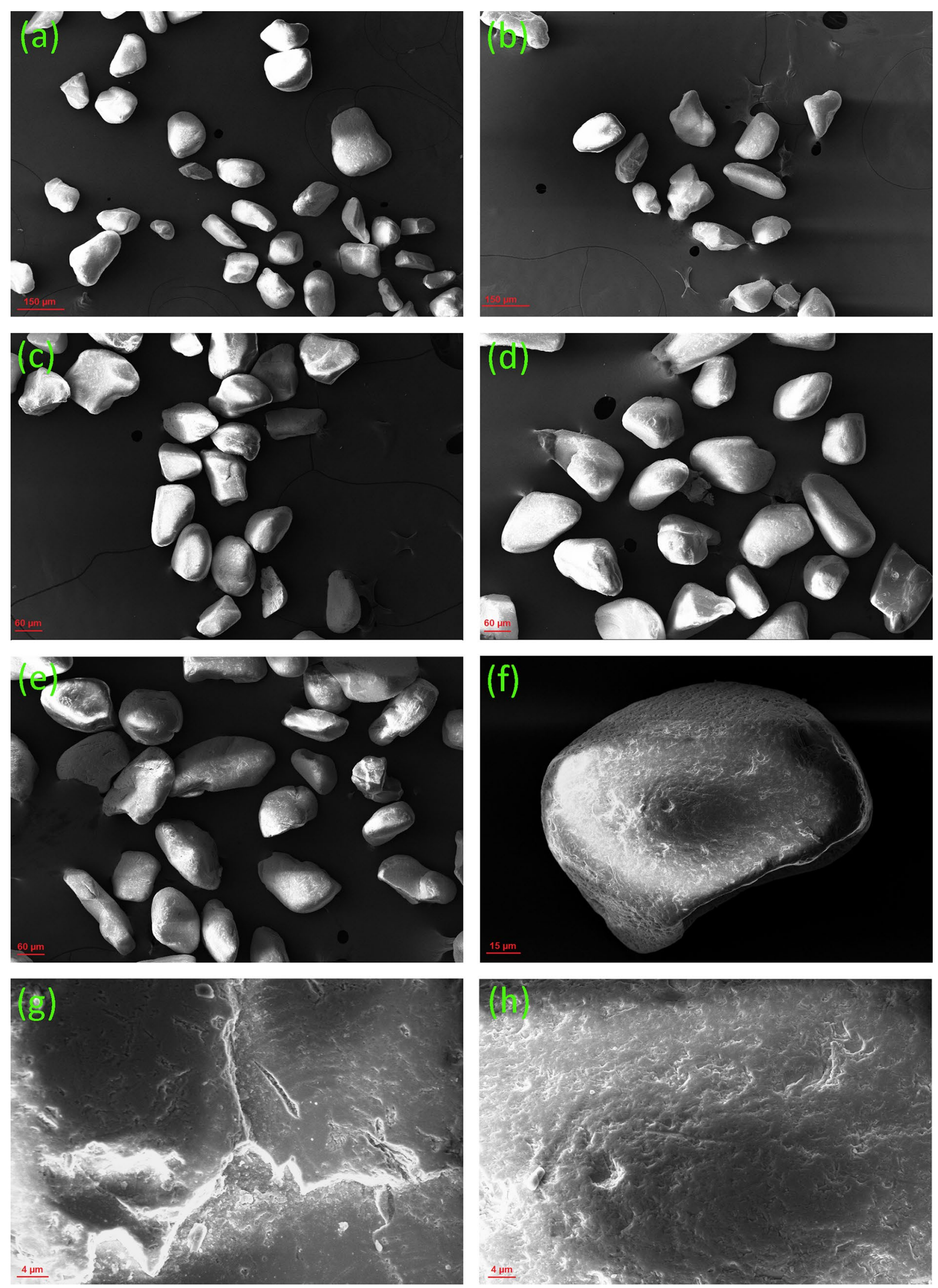

Fig. 10 SEM images of monazite mineral 
Table 7 SEM-EDS results of monazite

\begin{tabular}{|c|c|c|c|c|c|c|}
\hline \multirow[t]{2}{*}{ Element } & \multicolumn{2}{|l|}{ (a) } & \multicolumn{2}{|l|}{ (b) } & \multicolumn{2}{|l|}{ Average } \\
\hline & Weight (\%) & Atomic (\%) & Weight (\%) & Atomic (\%) & Weight (\%) & Atomic (\%) \\
\hline $\mathrm{CK}$ & 8.21 & 20.21 & 9.72 & 23.55 & 8.97 & 21.88 \\
\hline $\mathrm{OK}$ & 31.42 & 58.07 & 30.67 & 55.81 & 31.05 & 56.94 \\
\hline PK & 12.09 & 11.54 & 11.43 & 10.75 & 11.76 & 11.15 \\
\hline Ca K & 1.26 & 0.93 & 1.17 & 0.85 & 1.22 & 0.89 \\
\hline La L & 9.32 & 1.98 & 9.89 & 2.07 & 9.61 & 2.03 \\
\hline Ce L & 21.4 & 4.52 & 21.43 & 4.45 & 21.42 & 4.49 \\
\hline $\mathrm{Nd} \mathrm{L}$ & 8.55 & 1.75 & 7.18 & 1.45 & 7.87 & 1.6 \\
\hline Th M & 7.25 & 0.92 & 7.59 & 0.95 & 7.42 & 0.94 \\
\hline UM & 0.5 & 0.06 & 0.92 & 0.11 & 0.71 & 0.09 \\
\hline
\end{tabular}
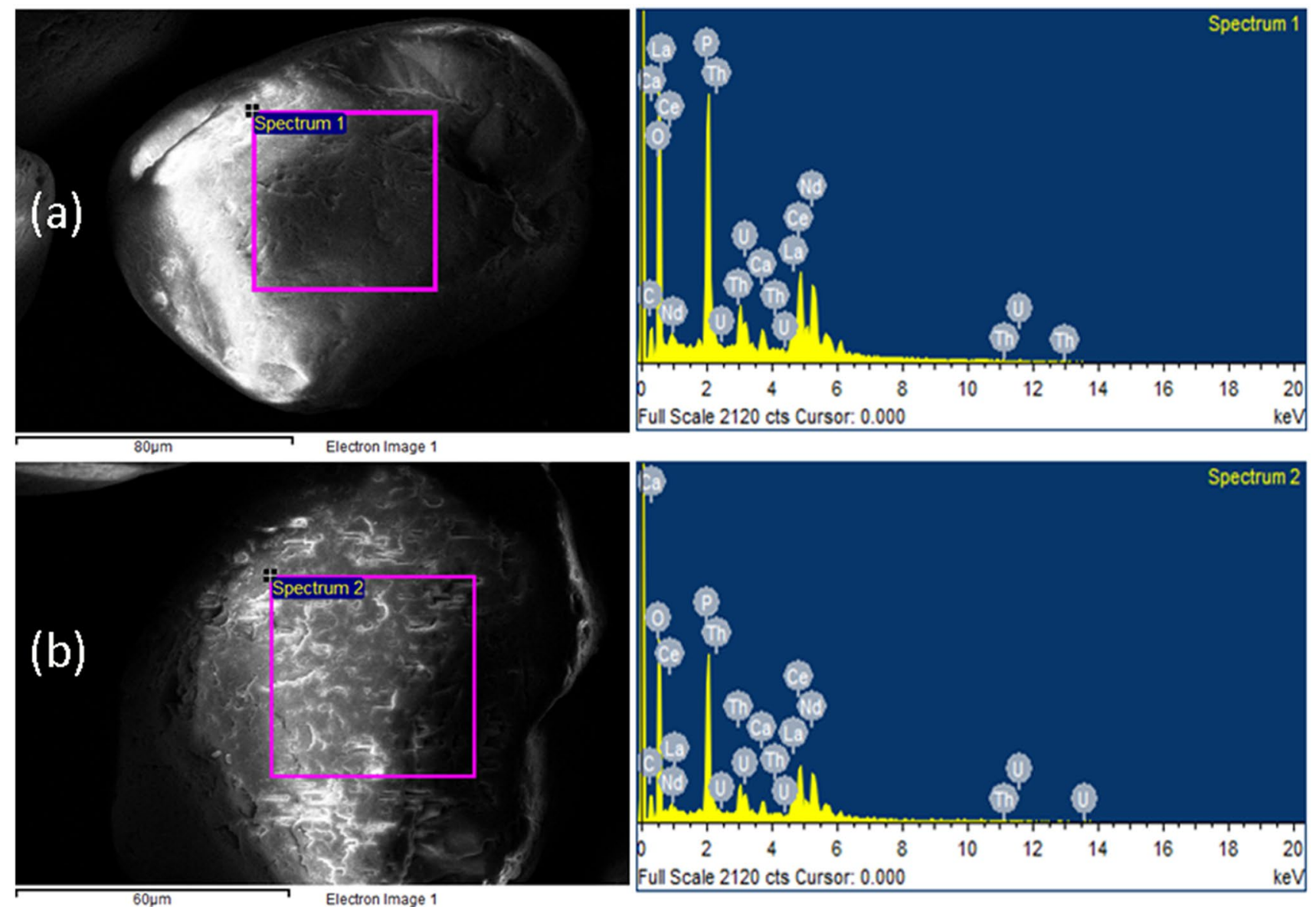

Fig. 11 SEM-EDS results

is similar to charnockites and gneisses of the Western Ghats [73]. The TDM ages (from 1884 to $2718 \mathrm{Ma}$ ) of the beach placer monazites is also similar to these rocks. Thus, the studies confirm that provenance of monazite mineral is Paleoproterozoic - late Neo archaean charnockites and gneisses that evolved from mantle source regions during Neo archaean.

\subsection{SEM-EDS analysis}

The micromorphology of monazite mineral was studied under the scanning electron microscope (SEM), and its chemistry was analyzed using EDS. Fig. 10a-h shows the SEM images of monazite mineral. The grains are subhedral and tabular in shape (Fig. 9a-e). The monazite grains 
Table 8 Bulk geochemistry of soil samples using ED-XRF (BDL-below detection level)

\begin{tabular}{|c|c|c|c|c|c|c|c|c|c|c|c|}
\hline Chemistry & SS1 & SS2 & SS3 & SS4 & SS5 & SS6 & SS7 & SS8 & SS9 & SS10 & Average \\
\hline $\mathrm{SiO}_{2}(\%)$ & 51.61 & 73.46 & 17.67 & 73.22 & 31.99 & 51.23 & 6.59 & 78.09 & 70.81 & 63.37 & 51.8 \\
\hline $\mathrm{TiO}_{2}(\%)$ & 15.75 & 5.84 & 44.59 & 7.94 & 27.8 & 13.41 & 52.98 & 4.43 & 8.93 & 11.68 & 19.34 \\
\hline $\mathrm{Fe}_{2} \mathrm{O}_{3}(\%)$ & 10.15 & 4.08 & 22.7 & 3.8 & 17.65 & 10.76 & 27.88 & 2.24 & 4.02 & 6.63 & 10.99 \\
\hline $\mathrm{Al}_{2} \mathrm{O}_{3}(\%)$ & 9.98 & 8.96 & 5.72 & 9.73 & 16 & 14.68 & 4.36 & 5.35 & 10.44 & 10.68 & 9.59 \\
\hline $\mathrm{CaO}(\%)$ & 7.49 & 3.68 & 0.97 & 1.04 & 1.61 & 4.65 & 0.23 & 6.84 & 1.2 & 3.25 & 3.1 \\
\hline $\mathrm{ZrO}_{2}(\%)$ & 1.6 & 0.4 & 5.55 & 2.55 & 1.49 & 1.81 & 5.15 & 0.56 & 2.77 & 0.76 & 2.26 \\
\hline $\mathrm{P}_{2} \mathrm{O}_{5}(\%)$ & 1.24 & 1.87 & 0.78 & 0.91 & 1.34 & 1.38 & 0.63 & 1.51 & 1.03 & 1.39 & 1.21 \\
\hline $\mathrm{MgO}(\%)$ & 0.71 & 0.86 & 0.4 & 0.1 & 0.75 & 0.58 & 0.44 & 0.44 & 0.09 & 0.99 & 0.54 \\
\hline $\mathrm{K}_{2} \mathrm{O}(\%)$ & 0.81 & 0.6 & 0.05 & 0.24 & 0.6 & 0.9 & BDL & 0.26 & 0.26 & 0.88 & 0.51 \\
\hline Cd (ppm) & BDL & BDL & 737.31 & BDL & BDL & BDL & 1260.5 & BDL & $\mathrm{BDL}$ & $\mathrm{BDL}$ & 998.91 \\
\hline V (ppm) & 784.23 & 285.01 & 2139.82 & 487.96 & 1534.84 & 756.22 & 2481.51 & 229.72 & 444.66 & 503.02 & 964.7 \\
\hline Mn (ppm) & 741.17 & 279.89 & 1804.52 & 178.67 & 1169.45 & 559.63 & 2230.48 & 191.06 & 225.37 & 438.2 & 781.84 \\
\hline $\mathrm{Hf}$ (ppm) & 449.93 & 93.28 & 1789.2 & 728.14 & 421.44 & 468.5 & 1695.92 & 117.7 & 663.11 & 206.99 & 663.42 \\
\hline $\mathrm{Nb}$ (ppm) & 391.61 & 143.03 & 1111.5 & 124.92 & BDL & 398.88 & 1251.31 & 119.96 & 178.33 & 282.14 & 444.63 \\
\hline Th (ppm) & 490.2 & 0 & 853.68 & 678 & 194.13 & 387.64 & 739.08 & 261.53 & 577.73 & 145.36 & 432.74 \\
\hline $\mathrm{Nd}(\mathrm{ppm})$ & 261.12 & BDL & 724.5 & 441.56 & BDL & 171.95 & 638.76 & 185.41 & 318.65 & $\mathrm{BDL}$ & 391.71 \\
\hline $\mathrm{Cr}(\mathrm{ppm})$ & 354.89 & 191.91 & 655.86 & 255.68 & 513.34 & 303.5 & 738.92 & 172.96 & 283.11 & 277.16 & 374.73 \\
\hline Zn (ppm) & 238.19 & 305.35 & 363.91 & 173.84 & 339.01 & 294.83 & 373.31 & 89.25 & 229.76 & 231.12 & 263.86 \\
\hline Eu (ppm) & 19.22 & 80.88 & 18.74 & BDL & 350.41 & 109.63 & 66.5 & BDL & BDL & 137.36 & 111.82 \\
\hline $\mathrm{Pb}(\mathrm{ppm})$ & 109.73 & 44.93 & 182.6 & 54.12 & 146.49 & 93.3 & 216.49 & 24.32 & 52.54 & 67.58 & 99.21 \\
\hline Sr (ppm) & 223.38 & 87.51 & 51.98 & 28.02 & 69.2 & 164.81 & 34.26 & 151.22 & 30.3 & 102.53 & 94.32 \\
\hline In (ppm) & 201.63 & 30.94 & 0 & $\mathrm{BDL}$ & 10.26 & 83.71 & BDL & 129.33 & BDL & $\mathrm{BDL}$ & 75.98 \\
\hline Y (ppm) & 63.86 & 20.08 & 143.54 & 94.17 & 64.96 & 68.9 & 128.03 & 32.52 & 107.17 & 32.44 & 75.57 \\
\hline Bi (ppm) & 11.93 & 92.57 & 163.35 & 9.42 & 45.3 & 15.34 & 243.27 & BDL & 13.1 & 8.34 & 66.96 \\
\hline Co (ppm) & BDL & 33.79 & BDL & $\mathrm{BDL}$ & 136.04 & 92.75 & BDL & 17.81 & BDL & 52.4 & 66.56 \\
\hline U (ppm) & BDL & BDL & BDL & 63.1 & $\mathrm{BDL}$ & BDL & $\mathrm{BDL}$ & BDL & BDL & $\mathrm{BDL}$ & 63.1 \\
\hline Ni (ppm) & 50.69 & 18.39 & 115.13 & BDL & 21.45 & 69.94 & 126.21 & BDL & BDL & 25.7 & 61.07 \\
\hline Rb (ppm) & 18.46 & 15.63 & 6.31 & $\mathrm{BDL}$ & 22.49 & 26.69 & 4.66 & BDL & $\mathrm{BDL}$ & 20.29 & 16.36 \\
\hline Ga (ppm) & 14.43 & 9.71 & 27.12 & BDL & 18.45 & 17.52 & BDL & 10.12 & 18.19 & 14.28 & 16.23 \\
\hline Yb (ppm) & BDL & BDL & BDL & $\mathrm{BDL}$ & $\mathrm{BDL}$ & BDL & $\mathrm{BDL}$ & $\mathrm{BDL}$ & 13.57 & BDL & 13.57 \\
\hline $\mathrm{Br}(\mathrm{ppm})$ & BDL & 9.5 & BDL & $\mathrm{BDL}$ & 18.3 & 14.6 & $\mathrm{BDL}$ & 10.7 & $\mathrm{BDL}$ & BDL & 13.28 \\
\hline Se (ppm) & $\mathrm{BDL}$ & BDL & 11.74 & BDL & 0.07 & BDL & 23.55 & BDL & $\mathrm{BDL}$ & BDL & 11.79 \\
\hline Ir (ppm) & $\mathrm{BDL}$ & 0.6 & BDL & BDL & 37.38 & BDL & BDL & 3.43 & BDL & 4.37 & 11.45 \\
\hline $\mathrm{Ta}(\mathrm{ppm})$ & BDL & BDL & BDL & BDL & BDL & BDL & BDL & 9.25 & BDL & BDL & 9.25 \\
\hline As (ppm) & $\mathrm{BDL}$ & 2.65 & BDL & BDL & BDL & $\mathrm{BDL}$ & BDL & 4.39 & 4.01 & BDL & 3.68 \\
\hline $\operatorname{Re}(p p m)$ & BDL & BDL & $\mathrm{BDL}$ & 2.6 & BDL & BDL & BDL & BDL & $\mathrm{BDL}$ & $\mathrm{BDL}$ & 2.6 \\
\hline
\end{tabular}

are elongated to subrounded in shape [74]. Physically attributed fractured features are also observed on the surface of the grains (Fig. 9g). Irregular pits, linear and irregular features formed by impact effects, are also present on the surface (Fig. 9f and h). These morphological features clearly reveal the various mechanical and chemical processes undergone by monazite mineral, especially the impact structures represents the high energy conditions and long transportation experienced by the monazite grains. Mallik (1986) suggests that these morphological features are indicators of polycyclic nature [75].

SEM-EDS provides a semi-quantitative analytical approach for establishing the existence of $\mathrm{La}, \mathrm{Ce}$, Th, and $\mathrm{U}$ in the monazite mineral [76]. The EDS analysis mainly shows the presence of $\mathrm{Ce}, \mathrm{La}, \mathrm{Nd}, \mathrm{Th}$, and $\mathrm{U}$. The rare earths like $\mathrm{Ce}, \mathrm{La}$, and $\mathrm{Nd}$ present around $21.42,9.61$, and $7.87 \%$ by weight, respectively. The radioactive elements like Th and $U$ present around 7.42 and $0.71 \%$ by weight. The values of Th. $\mathrm{U}, \mathrm{Ce}$, and other rare earth results show a strong correlation with the results of Jeya et al. (2008) 
[64] and the ED-XRF results. The results of SEM-EDS were summarized in Table 7 and Fig. 11.

The monazite mineral grains are mounted on a metal stub using a sticky carbon disc for SEM-EDS analysis. The presence of carbon tapes may give the values of $C$ [65]. The value 8.21 corresponds to $\mathrm{C}$ not Al. The presence of $\mathrm{Al}$ or $\mathrm{Al}_{2} \mathrm{O}_{3}$ in monazite cannot be determined using EDS. The EDS measurements are carried out for single monazite grains, and the higher values of rare earths and radioactive elements in EDS results confirm that it is monazite. The columns (a) and (b) in Table 7 shows the EDS analysis of two monazite grains which are clearly shown in Fig. 11.

\subsection{Bulk geochemistry of soil samples}

The ED-XRF analysis gives the chemical composition as major oxides and trace elements, which helps to identify the presence of heavy minerals, mainly the monazite mineral in soil samples. The ED-XRF technique provides a rapid multi-elemental analysis of geological samples, especially the major, trace, radioactive, and rare earth elements in soil and beach sediments [77, 78]. These results paved the qualitative confirmation of minerals present in the soil [79]. The results are shown in Table 8. The major oxides present in the order of $\mathrm{SiO}_{2}>\mathrm{TiO}_{2}>\mathrm{Al}_{2} \mathrm{O}_{3}>\mathrm{CaO}>\mathrm{ZrO}_{2}>\mathrm{P}_{2} \mathrm{O}_{5}>\mathrm{MgO}>\mathrm{K}_{2} \mathrm{O}$, and trace elements are in the order of $\mathrm{Cd}>\mathrm{V}>\mathrm{Mn}>\mathrm{Hf}>\mathrm{Nb}>\mathrm{T}$ $\mathrm{h}>\mathrm{Nd}>\mathrm{Cr}>\mathrm{Zn}>\mathrm{Eu}>\mathrm{Pb}>\mathrm{Sr}>\mathrm{In}>\mathrm{Co}>\mathrm{U}>\mathrm{Ni}>\mathrm{Rb}>\mathrm{Ga}>$ $\mathrm{Yb}>\mathrm{Br}>\mathrm{Se}>\mathrm{Ir}>\mathrm{Ta}>\mathrm{As}>\mathrm{Re}$. The high $\mathrm{SiO}_{2}$ content in the soil indicates the presence of light minerals like quartz. The presence of $\mathrm{TiO}_{2}$ and $\mathrm{FeO}_{3}$ suggest the presence of ilmenite, rutile, leucoxene, etc., and the Th, $U$, and REE suggest the presence of monazite mineral. The sample SS7 with ilmenite content of $77.6 \%$ corresponds to $52.98 \% \mathrm{TiO}_{2}$ and $27.88 \% \mathrm{Fe}_{2} \mathrm{O}_{3}$. Monazite is maximum for $\mathrm{SS} 3$ with $1.4 \%$. The sample SS3 corresponds to maximum Th content of $853.68 \mathrm{ppm}$, and the nearby location SS4 corresponds to maximum $U$ content of $63.1 \mathrm{ppm}$. The high silica content of the samples such as SS2, SS4, SS8, and SS9 results in high $\mathrm{SiO}_{2}$ values of around $70 \%$. The soil geochemistry shows good matching with the results of the heavy mineral analysis carried out on soil samples (given in Table 4).

\section{Conclusion}

The combination of ED-XRF and SEM-EDS is an effective method for determining the chemical composition and surface morphological characteristics of monazite mineral. Using these techniques, major chemical constituents of the monazite mineral in the beach sands of Neendakara-Kayamkulam belt, Kerala, India, were determined. The SEM provides high-resolution images that precisely show the weathering mechanism, both mechanical and chemical, that occurred in monazite mineral. The texture and mineralogy of beach sediments give a clear picture of the distribution of strategic heavy minerals along the coast, which can guide for potential target exploration. Effective recovery of high-grade monazite mineral can be achieved by a judicious combination of magnetic, electrostatic, and gravity separation techniques. Evaluation of economically important monazite mineral using advanced chemical characterization techniques provides solid information to policymakers and scientific community for better utilization and exploration of mineral deposits.

Acknowledgements The first author thanks the Dr. Asanani, former DT, IREL, Mumbai for granting permission to carry out the test works at IRERC, Kollam.

\section{Compliance with ethical standards}

Conflict of interest The authors declare that they have no conflict of interest.

\section{References}

1. Tipper GH (1914) The monazite sands of Travancore. Recruit Geol Surv India 44(3):186-196

2. Abdel-Karim AAM, Zaid SM, Moustafa MI, Barakat MG (2016) Mineralogy, chemistry and radioactivity of the heavy minerals in the black sands, along the northern coast of Egypt. J Afr Earth Sci 123:10-20

3. Castor SB, Hedrick JB (2006) Rare earth elements. Industrial minerals volume, 7th edition: Society for mining, metallurgy, and exploration, Littleton, Colorado, pp 769-792

4. Dostal J (2017) Rare earth element deposits of alkaline igneous rocks. Resour 6(3):34

5. Shuaibu HK, Khandaker MU, Alrefae T, Bradley DA (2017) Assessment of natural radioactivity and gamma-ray dose in monazite rich black Sand Beach of Penang Island, Malaysia. Mar Pollut Bull 119(1):423-428

6. Kanse SD, Sahoo BK, Gaware JJ, Prajith R, Sapra BK (2016) A study of thoron exhalation from monazite-rich beach sands of High Background Radiation Areas of Kerala and Odisha. India. Environ Earth Sci 75(23):1465(1-10)

7. Larijani C, Schwendner P, Cockell C, Ivanov P, Russell B, AitkenSmith P, Pearce AK, Regan PH (2017) Destructive and nondestructive measurements of NORM in monazite-rich sands of Brazil. Radiat Phys Chem 140:180-185

8. Punniyakotti J, Ponnusamy VV (2017) Mineralogical role on natural radioactivity content in the intertidal sands of Tamilnadu coast (HBRAs region), India. J Radioanal Nucl Chem 314(2):949-959

9. Palaparthi J, Chakrabarti R, Banerjee S, Guin R, Ghosal S, Agrahari S, Sengupta D (2017) Economically viable rare earth element deposits along beach placers of Andhra Pradesh, eastern coast of India. Arabian J Geosci 10(9):201 
10. Ali MY, Hibberd P, Stoikovich B (2018) Origin and prospectivity of heavy mineral enriched sand deposits along the Somaliland coastal areas. J Afr Earth Sci 140:60-75

11. Shah AK, Bern CR, Van Gosen BS, Daniels DL, Benzel WM, Budahn JR, Davis R (2017) Rare earth mineral potential in the southeastern US Coastal Plain from integrated geophysical, geochemical, and geological approaches. GSA Bull 129(9-10):1140-1157

12. Shrivastava HB, Rupa NR, Rao VK, Raghavender B, Sharma PK (2018) Estimation of uranium concentration in Indian monazite samples by using HPGe semiconductor detector. App Rad Isotopes 141:21-23

13. Pruseth KL, Sahoo D, Kumar B, Kumar V (2017) Beach monazites from Alleppey: a window to the Trivandrum Block, Southern India. J Geol Soc India 89(3):240-246

14. Rajganapathi VC, Jitheshkumar N, Sundararajan M, Bhat KH, Velusamy S (2013) Grain size analysis and characterization of sedimentary environment along Thiruchendur coast, Tamilnadu, India. Arab J Geosci 6(12):4717-4728

15. Chaudhri RS, Khan HM, Kaur S (1981) Sedimentology of beach sediments of the West coast of India. Sediment Geol 30(1-2):79-94

16. Rajamanickam Gujar (1993) Depositional processes inferred from the log probability distribution. In: Jhingran V (ed) Recent researches in sedimentolgy. Hindustan Publishing Corporation, Delhi, pp 154-164

17. Rao PS, Ramaswamy V, Thwin S (2005) Sediment texture, distribution and transport on the Ayeyarwady continental shelf, Andaman Sea. Mar Geol 216(4):239-247

18. Angusamy N, Rajamanickam GV (2006) Depositional environment of sediments along the southern coast of Tamil Nadu, India. Oceanologia 48(1):87-102

19. Gandhi MS, Solai A, Chandrasekaran K, Rammohan V (2008) Sediment characteristics and heavy mineral distribution in Tamiraparani Estuary and Off Tuticorin, Tamil Nadu-SEM Studies. Earth Sci India III:102-118

20. Ramanathan AL, Rajkumar K, Majumdar J, Singh G, Behera PN, Santra SC, Chidambaram S (2009) Textural characteristics of the surface sediments of a tropical mangrove Sundarban ecosystem India. Indian J Mar Sci 38(4):397-403

21. Gayathri GS, Rejith RG, Jeelani SH, Sundararajan M, Aslam MM, Chidambaram S (2017) Heavy mineral resources in Tamil Nadu, India: an overview. In: Geochemistry and Mineralogy of Coastal Sediments in Tamil Nadu, Aarhat Publication \& Aarhat Journal's, Badlapur, pp 110-121

22. Sajimol S, Rejith RG, Lakshumanan C, Sundararajan M (2017) Sedimentology and geochemistry of heavy mineral deposits along the coast of Kanyakumari district, Tamil nadu, India. In: Geochemistry and Mineralogy of Coastal Sediments in Tamil Nadu, Aarhat Publication \& Aarhat Journal's, Badlapur, pp 145-161

23. Wang S, Li J, Wu S, Yan W, Huang W, Miao L, Chen Z (2016) The distribution characteristics of rare metal elements in surface sediments from four coastal bays on the northwestern South China Sea. Estuar Coast Shelf Sci 169:106-118

24. Rozendaal A, Philander C, Heyn R (2017) The coastal heavy mineral sand deposits of Africa. South Afr J Geol 120(1):133-152

25. Amalan K, Ratnayake AS, Ratnayake NP, Weththasinghe SM, Dushyantha N, Lakmali N, Premasiri R (2018) Influence of nearshore sediment dynamics on the distribution of heavy mineral placer deposits in Sri Lanka. Environ Earth Sci 77(21):737

26. Dobbins M, Domenico J, Dunn P (2007) A discussion of magnetic separation techniques for concentrating ilmenite and chromite ores. In: The 6th international heavy minerals conference "back to basics", The Southern African Institute of Mining and Metallurgy, pp 197-204
27. Zhang J, Edwards C (2012) A review of rare earth mineral processing technology. In: 44th annual meeting of the Canadian mineral processors. CIM, Ottawa, pp 79-102

28. Jordens A, Sheridan RS, Rowson NA, Waters KE (2014) Processing a rare earth mineral deposit using gravity and magnetic separation. Min Eng 62:9-18

29. Rejith RG, Sundararajan M (2018) Combined magnetic, electrostatic, and gravity separation techniques for recovering strategic heavy minerals from beach sands. Mar Geores Geotech 36(8):959-965

30. Laxmi T, Behera JR, Rao RB (2016) Beneficiation studies on recovery of ilmenite from red sediments of badlands topography, Andhra Pradesh. Adv Sci Lett 22(2):344-348

31. Kim K, Jeong S (2019) Separation of monazite from placer deposit by magnetic separation. Minerals 9(3):149(1-12)

32. Krishnan S, Viswanathan G, Balachandran K (2001) Heavy mineral sand deposits of Kerala. Explor Res Atom Min 13:111-146

33. Soman K (1985) Origin and geological significance of the Chavara placer deposit, Kerala. Curr Sci 54(6):280-281

34. Narayanaswamy DSSB, Bobby Prasanth MS (2004) Zircon morphological characteristics from two major placer deposits of South India (Chavara and Manavalakurichi) and their significance on provenance. In: Loveson VJ, Misra DD (eds) Proceedings of the Placer-2004, Allied Publishers, New Delh, pp 79-84

35. Kurian NP, Prakash TN, Jose F, Black KP (2001) Hydrodynamic processes and beach placer deposits of SW coast of India. J Coast Res Spec Issue 34:154-163

36. Bernstein S, Frei D, McLimans RK, Knudsen C, Vasudev VN (2008) Application of CCSEM to heavy mineral deposits: source of highTi ilmenite sand deposits of South Kerala beaches, SW India. J Geochem Exp 96(1):25-42

37. Anooja S, Padmalal D, Maya K, Mohan SV, Baburaj B (2013) Heavy mineral contents and provenance of Late Quaternary sediments of southern Kerala, Southwest India. Indian J Geo Mar Sci 42(6):749-757

38. Milner I (1962) Sedimentary petrology. George Allen \& Unwin Ltd., London, pp 643-715

39. Folk RL, Ward WC (1957) Brazos River bar: a study in the significance of grain size parameters. J Sedim Res 27:3-26

40. Childs C (2004) Interpolating surfaces in ArcGIS spatial analyst. ArcUser, July-September: 32-35

41. Rejith RG, Sundararajan M, Kaliraj S (2018) A geo-processing modeling of deltaic suspended sediment variability. J Geovis Spat Anal 2(2):13(1-15)

42. Sahu BK (1964) Depositional mechanisms from the size analysis of clastic sediments. J Sed Pet 34(1):73-83

43. Ravishankar SA, Kolla H (2009) Chemically enhanced electrostatic separation. In: The 7th international heavy mineral conference 'what next', Heavy minerals, South Africa: 203-206

44. Ferron CJ, Bulatovic SM, Salter RS (1991) Beneficiation of rare earth oxide minerals. Mater Sci Forum Trans Tech Publ $70: 251-270$

45. Arvidson BR (2001) The many uses of rare-earth magnetic separators for heavy mineral sands processing. Int Heavy Miner Conf 200:131-136

46. Naik PK (2002) Quantification of induced roll magnetic separation of mineral sands. Scandinavian J Mett 31(6):367-373

47. Tripathy SK, Singh V, Suresh N (2015) Prediction of separation performance of dry high intensity magnetic separator for processing of para-magnetic minerals. J Inst Eng Ser D 96(2):131-142

48. Mohanan S, Tripathy SK, Ramamurthy Y, Kumar CR (2012) Application of high tension roll separator for the separation of titanium bearing minerals: process modeling and optimization. J Min Mat Charac Eng 11(10):1005-1011 
49. Elder J, Yan E (2003) eForce.-Newest generation of electrostatic separator for the minerals sands industry. In: Heavy minerals conference, Johannesburg, South African Institute of Mining and Metallurgy, pp 63-70

50. Venter JA, Vermaak MKG, Bruwer JG (2008) Influence of surface effects on the electrostatic separation of zircon and rutile. J Southern Afr Inst Mind Metall 108(1):55-60

51. Irudhayanathan A, Thirunavukkarasu R, Senapathi V (2011) Grain size characteristics of the Coleroon estuary sediments, Tamilnadu, East coast of India. Carpathian J Earth Environ Sci 6(2):151-157

52. Friedman GM (1962) On sorting, sorting coefficients, and the lognormality of the grain-size distribution of sandstones. J Geol 70(6):737-753

53. Ray AK, Tripathy SC, Patra S, Sarma VV (2006) Assessment of Godavari estuarine mangrove ecosystem through trace metal studies. Environ Int 32(2):219-223

54. Sutherland RA, Lee CY (1994) Discrimination between coastal subenvironments using textural characteristics. Sedimentology 41(6):1133-1145

55. Griffths IC (1967) Scientific methods in the analysis of sediments. McGraw-Hill, New York, p 508

56. Folk RL (1966) A review of grain-size parameters. Sediment 6(2):73-93

57. Passega R (1964) Grain size representation by CM patterns as a geologic tool. J Sed Res 34(4):830-847

58. Visher GS (1969) Grain size distributions and depositional processes. J Sed Res 39(3):1074-1106

59. Shahul Hameed TS, Kurian NP, Thomas KV, Rajith K, Prakash TN (2007) Wave and current regime off the southwest coast of India. J CoasRes 23(5):1167-1174

60. Pettijohn FJ (1984) Sedimentary rocks, 3rd edn. Harper and Row, New York, pp 1-614

61. Ali MA, Krishnan S, Banerjee DC (2001) Beach and inland heavy mineral sand investigations and deposits in india-An overview. Atom Min Dir Explor Res Dep Atomic Energy Gov India 13:1-21

62. Vishwanathan $P$ (1957) Studies of Travancore beach sands. Indian Min J Spec issue 9957:1109-1922

63. Panda R, Kumari A, Jha MK, Hait J, Kumar V, Kumar JR, Lee JY (2014) Leaching of rare earth metals (REMs) from Korean monazite concentrate. J Ind Eng Chem 20(4):2035-2042

64. Jeya RJ, Balasubramanian G, Thampi PK (2008) Determination of rare earth elements in Indian coastal monazite by ICP-AES and ICP-MS analysis and their geochemical significance. Curr Sci 94(10):1296-1302

65. Udayakumar S, Rezan SA, Noor AFM, Putra TAR, Takip KM, Hazan $\mathrm{R}$ (2018) Characterization of Malaysian monazite concentrate for the recovery of thorium dioxide. J Phys Conf Ser 1082(1):012090

66. Shahr El-Din AM, Borai EH, Abd El-Ghany MS (2018) Selective separation of thorium from rare earth elements liquor during the alkaline processing of Egyptian monazite concentrate. Main Group Chem 17(1):79-88
67. Bangaku N, Reddy KSN, Ravi S, Ganapati R, Murali K (2016) REE geochemistry of monazites from coastal sands between Bhimunipatnam and Konada, Andhra Pradesh, East Coast of India. Curr Sci 110(8):1550-1559

68. Itano K, lizuka T, Hoshino M (2018) REE-Th-U and Nd isotope systematics of monazites in magnetite-and ilmenite-series granitic rocks of the Japan arc: implications for its use as a tracer of magma evolution and detrital provenance. Chem Geol 484:69-80

69. Itano K, Ueki K, lizuka T, Kuwatani T (2020) Geochemical discrimination of monazite source rock based on machine learning techniques and multinomial logistic regression analysis. Geosci 10(2):63

70. Mallikharjuna Rao M, Divakara Rao V, Murthy NN (1999) Charnockite from EGMB-geochemistry, protoliths character and tectonic relevance. Gond Res Mem 5:31-50

71. Murthy NN, Divakararao V (1999) Geochemistry, provenance and depositional environment of the khondalites from the Eastern Ghats Mobile Belts. Gondwana Res Group Memoir 5:15-30

72. Pandey UK, Chandrasekaran S (2010) Geochronological studies (207 Pb/206 Pbradiogenic and Sm-Nd) on monazites and zircons from beach placers of Tamil Nadu and Kerala: evidences on Pan-African Event and their Provenances. Int J Earth Sci Eng 3(03):323-331

73. Perumalsamy C (2015) Geochemical, Sm-Nd and Pb isotopic studies on beach placer monazites from south-western coast of India: importance of monazites as indicator of the tectonothermal evolution of source regions. Ph.D. Thesis submitted to Pondicherry University

74. Gonçalves CC, Braga PF (2019) Heavy mineral sands in Brazil: deposits, characteristics, and extraction potential of selected Areas. Minerals 9(3):176

75. MallikTK (1986) Micromorphology of some placer minerals from Kerala beach, India. Marine Geol 71(3-4):371-381

76. Dung NT, Bac BH, Van Anh TT (2017) Distribution and reserve potential of titanium-zirconium heavy minerals in Quang an Area, Thua Thien Hue Province, Vietnam. In: International conference on geo-spatial technologies and earth resources. Springer, Cham, pp 326-339

77. Zambello FR, Enzweiler J (2002) Multi-element analysis of soils and sediments by wavelength-dispersive $\mathrm{X}$-ray fluorescence spectrometry. J Soil Sedim 2(1):29-36

78. Oyedotun TDT (2018) X-ray fluorescence (XRF) in the investigation of the composition of earth materials: a review and an overview. Geol Ecol Landsc 2(2):148-154

79. Singh V, Agrawal H (2012) Qualitative soil mineral analysis by EDXRF, XRD and AAS probes. Radiat Phys Chem 81(12):1796-1803

Publisher's Note Springer Nature remains neutral with regard to jurisdictional claims in published maps and institutional affiliations. 